Historic, Archive Document

Do not assume content reflects current scientific knowledge, policies, or practices. 



\section{FALL CATALOGUE 1915 CRAIG SPECIALTIES}

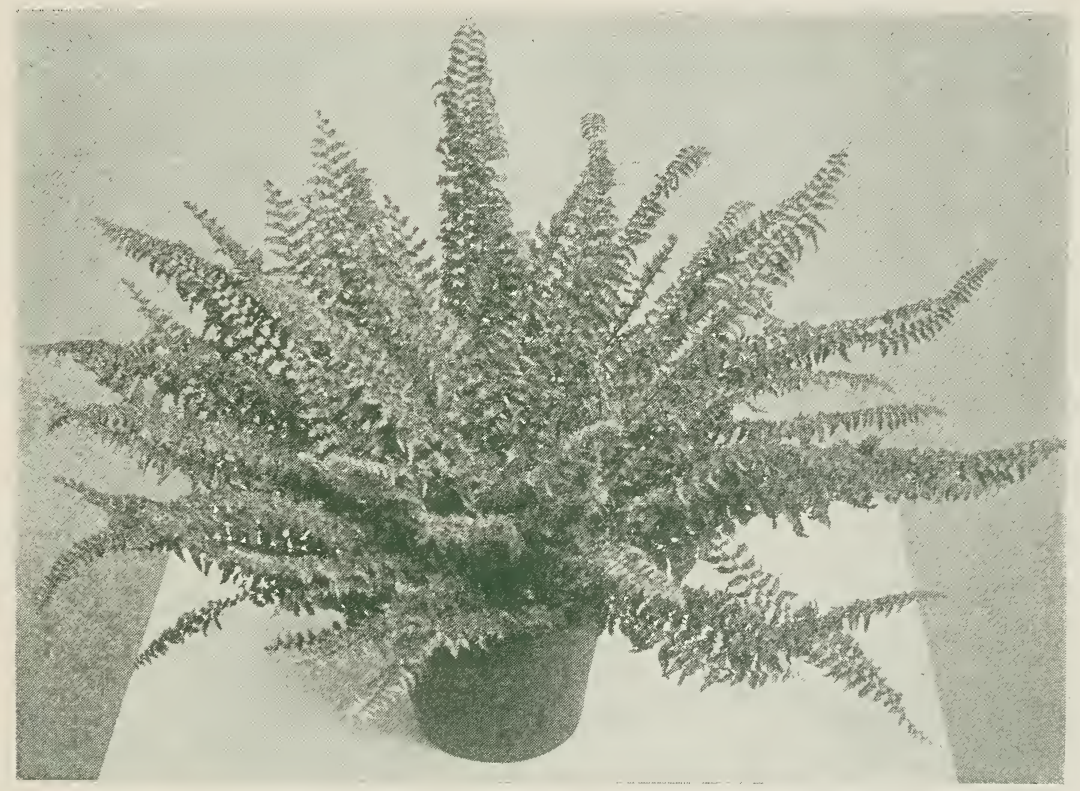

NEW NEPHROLEPIS JOHN WANAMAKER

"The Wanamaker Boston Fern"

\section{ROBERT CRAIG COMPANY} 4900 MARKET STREET - PHILADELPHIA, PA. BRANCH : NORWOOD, PA. 


\section{To Our Customers}

CRAIG SPECIALTIES are known all over the country and are in greater demand each year. Having increased our glass area over 100,000 square feet, we are in a position to meet our fast increasing business. Our stock for the Fall and Christmas season is superior in quality to any we have ever grown, notwithstanding the high standard we have maintained for years. Any buyer seeking quality will be repaid by inspecting our immense stock at both our Philadelphia and Norwood establishments.

We extend to all a very cordial invitation to call, feeling assured your visit will be both a pleasure and a profit. If unable to call you may send us your order, large or small, with every confidence that it will have our best attention. We would suggest placing orders as early as possible.

\section{TERMS:-}

CASH WITH ORDER. Kindly send sufficient to cover the entire bill. We do not make shipments C. O. D. unless remittance has been made on account to guarantee acceptance. This does not apply to regular customers.

REMITTANCES:- Remittances should be made by money order or New York drafts. If money is sent, letter should be registered. All prices quoted in this list are strictly net.

SHIPPING INSTRUCTIONS:-Give your name, post office, county and state, and the name of your nearest express office to which shipment is to be made.

CORRESPONDENCE:-We endeavor to answer all correspondence promptly, but owing to the pressure of business during the Fall rush we ask that all requests be clearly and concisely stated.

ERRORS:-Keep a copy of your order. We aim to have our orders correctly filled. Where we are at fault we shall make satisfactory correction. 


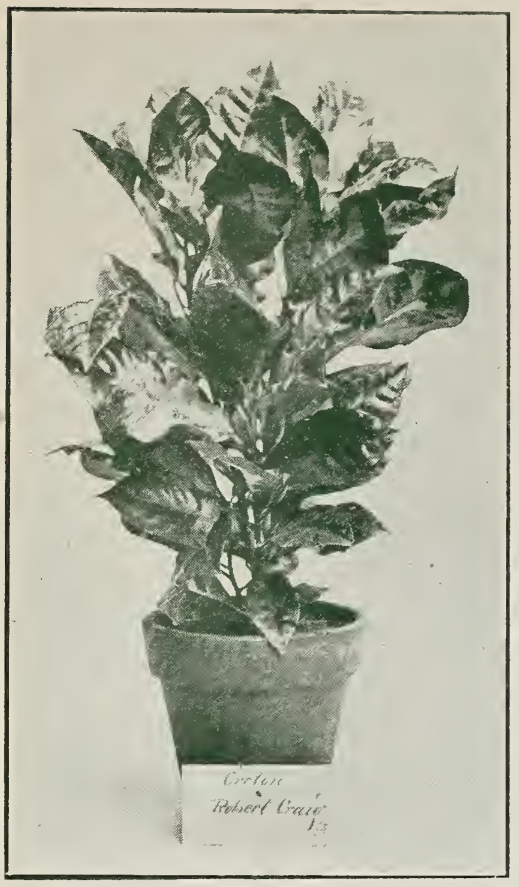

NEW SEEDLING CRO'TON
ROBERT CRATG

\section{CROTONS}

The Croton, with its highly-colored foliage, is indispensable during Spring and Summer. We have the largest and most complete collection of Crotons in the world, carrying at the present time for Fall sales over 50,000 plants in 200 varieties, all of the very highest quality and brilliantly colored.

$21 / 2$-inch pots, strong plants . . \$ \$20 per $100 ; \$ 175$ per 1,000

4 -inch pots, strong plants ....\$30 per $100 ; \$ 275$ per 1,000

5 -inch pots, strong plants .... \$50, $\$ 75$ and $\$ 100$ per 100

6 -inch pots, strong plants . $\$ 12, \$ 15, \$ 18$ and $\$ 24$ per doz.

7 -inch pots, strong plants ..... \$24, \$30 and $\$ 36$ per doz.

8 -inch pots, made up, beautiful plants,

10 -inch pots, made up, beautiful plants, $\$ 24, \$ 30$ and $\$ 36$ per doz.

12 -inch and 14-inch, made up, beautiful plants, $\$ 10, \$ 15$ and $\$ 20$ each

Every retail store and grower should feature Crotons this Fall and Christmas. We know our stock will please you and your customer.

\section{CROTON PUNCTATA}

One of the finest and most satisfactory varieties for basket work and centers of ferneries.

$21 / 2$-inch pots ...........\$8 per $100 ; \$ 75$ per 1,000 3 -inch pots ........... \$20 per $100 ; \$ 150$ per 1,000

4 -inch pots .......... \$25 per $100 ; \$ 225$ per 1,000

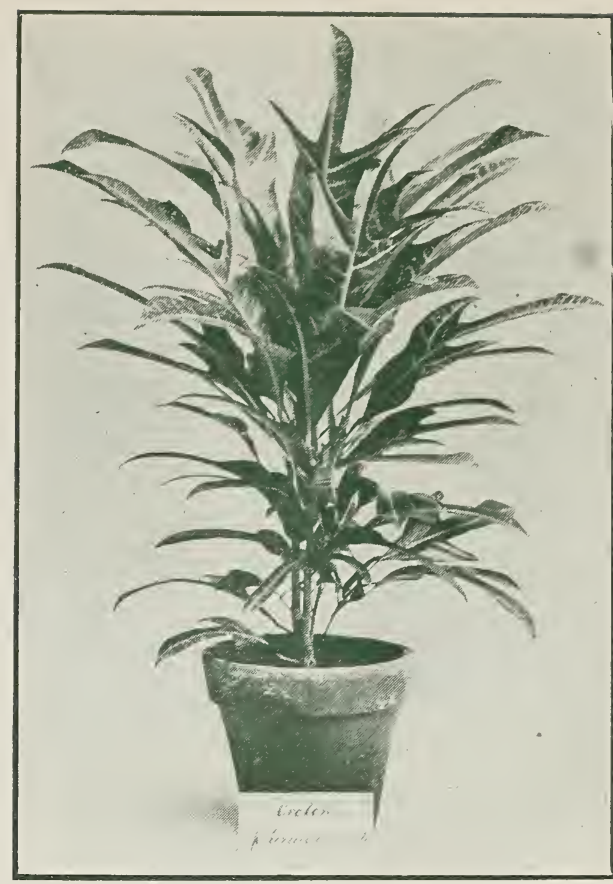

CROTON NORWOOD BEAUTY

\section{CROTON NORWOOD BEAUTY}

This variety is one of the best of our seedlings raised three years ago, and we are now in a position to offer same in quantity and at very reasonable prices. This variety has an oak-shaped leaf and is brilliantly colored red, yellow and orange.

4 -inch pots, heavy . .\$6 per doz.; $\$ 40$ per 100 5-inch pots, heavy .....\$9 and $\$ 12$ per doz. 6 -inch pots, heavy $\ldots \ldots \ldots \ldots \ldots 18$ per doz. 7 -inch pots, heary .....\$2.50 and $\$ 3$ each

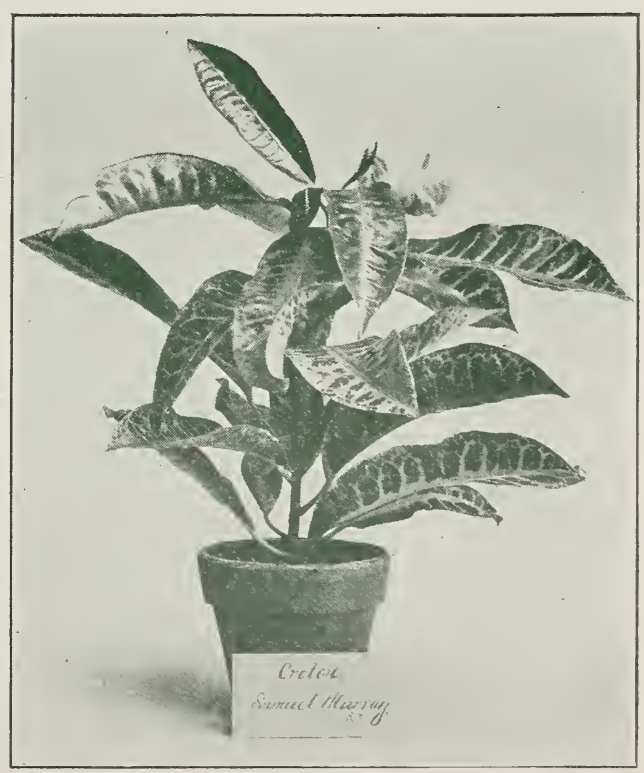

NEW SEEDLING CROTON SAMUEL MURRAY 




NEW SEEDLING CROTON

MRS. A. A. ALBRIGHT

\section{CROTON CHANTRIERII MAJOR}

One of the best of the French introductions. Very large leaf; brilliantly colored red and yellow.

4 -inch pots .............. \$6 per doz.; $\$ 40$ per 100 5 -inch and $51 / 2$-inch pots....\$0.75, $\$ 1, \$ 1.25$ and $\$ 1.50$ each 7 -inch pots ............... \$2, $\$ 2.50$ and $\$ 3$ each

\section{CROTON REEDII}

One of the most beautiful and always a satisfactory variety-wonderful keeper. Our stock of this variety is the largest in the country.

5 -inch pots, heary...........\$12 and $\$ 15$ per doz. 6 -inch pots, heavy...........\$18 and $\$ 24$ per doz.

\section{CROTONS (NARROW LEAF TYPE)}

\section{Delicatissima, Golden Thread and Florence}

These varieties are indispensable for table decoration and we predict a great future for them, as nothing surpasses them for use in artistic arrangement.

$2 \frac{1}{4}$-inch pots, heavy ................\$25 per 100

4 -inch pots, heavy . . . . . . . . . . \$50 per 100

5 -inch pots, heavy ............. \$0.75 and $\$ 1$ each

6 -inch pots, heary ..........\$15 and $\$ 18$ per doz.

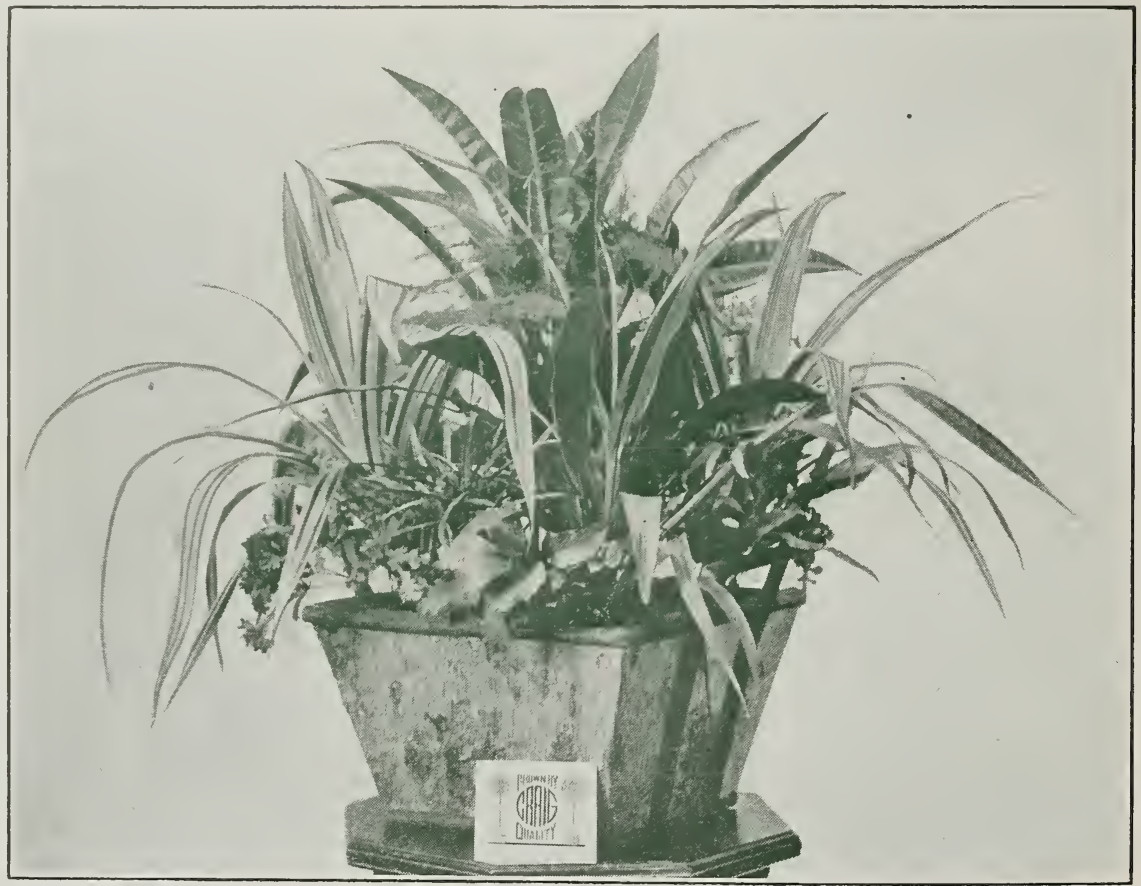

\section{DRACAENAS}

There is no variety of foliage plant as attractive as the highly colored Dracaena. The small and medium sizes can be used to great advantage in making up the popular Christmas baskets, while the large specimens have always been in great demand for decorative purposes. We are now growing more Dracaenas, in greater variety, than any firm in this country.

\section{PLANT COMBINATION BASKET}

\section{DRACAENA GODSEFFIANA}

Green and white leaf, very hardy; fine for baskets.

$21 / 4$-inch pots......\$10 per 100

3 -inch pots......\$15 per 100 4 -inch pots......\$25 per 100

\section{DRACAENA MASSANGEANA}

The variety with the golden stripe down the center of the leaf. This handsome plant is the best of all Dracaenas for the house. We have an exceptionally large stock, well colored and of the very highest quality. We have the largest and finest stock in the country.

4-inch pots, heavy,

$\$ 7.50$ per doz.; $\$ 50$ per 100 6 -inch pots, heavy, $\$ 15$ and $\$ 18$ per doz. 8 -inch pots, heavy, $\$ 2, \$ 2.50$ and $\$ 3$ each 10-inch pots, heavy, $\$ 3.50, \$ 4$ and $\$ 5$ each 12-inch tubs, heavy, $\$ 6$ and $\$ 7.50$ each 



NEW SEEDLING CROTON RODMAN WANAMAKER

DRACAENA MASSANGEANA

\section{DRACAENA FRAGRANS}

Plain green leaf.

4 -inch pots $\ldots \ldots \ldots \ldots \ldots \ldots \$ 5$ per doz. 6 -inch pots ......\$6 and $\$ 9$ per doz. 8 -inch pots ......... \$18 per doz. 10 -inch pots .......\$3 and $\$ 4$ each

\section{DRACAENA LORD WOLSELEY}

One of the very best varieties for Christmas, being bright red in color. An excellent Christmas variety.

2-inch pots .......... \$12 per 100 3 -inch pots, very heavy $\ldots \ldots . \$ 25$ per 100 4 -inch pots, very heavy $\ldots \ldots . \$ 35$ per 100 5 -inch pots, very heavy, $\$ 7.50$ and $\$ 9$ per doz. 6-inch pots, very heavy, $\$ 12$ and $\$ 15$ per doz. 7 -inch pots, very heary, $\$ 2$ and $\$ 2.50$ each



DRACAENA LORD WOLSELEY 




DRACAENA SANDERIANA
DRACAENA SANDERIANA

Small, light-green leares, edged with ereamy white Fine for center of fern dishes or basket work.

$21 / 2$-inch pots................\$15 per 100

\section{DRACAENA BAPTISTII}

Long, hroad foliage; cream, red and orange.

$21 / 2$-inch pots................... \$20 per 100

3 -inch pots.................\$35 per 100

4 -inch pots.................. $\$ 6$ per doz.

5 -inch pots...........\$9 and $\$ 12$ per doz.

6 -inch pots........... $1, \$ 1.25$ and $\$ 1.50$ each

7 -inch pots............. $\$ 2$ and $\$ 2.50$ each

\section{DRACAENA AMABILIS}

Green and Pinkish White, Very Fine

$21 / 2$-inch pots................. \$20 per 100 -inch pots................\$35 per 100 -inch pots................\$50 per 100

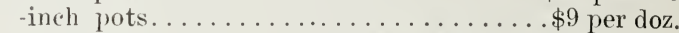
-inch pots..........\$12, $\$ 15$ and $\$ 18$ per doz -inch pots................50 each

\section{DRACAENA STRICTA GRANDIS Carmine Red Leaves}

21/2-inch pots................\$20 per 100

3 -iuch pots................. \$35 per 100

+ -inch pots..................\$50 per 100

(i) inch pots............ 12 and $\$ 15$ per doz.

\section{DRACAENA KELLERIANA (NEW)}

The greatly improred Godseffiana. One of the finest foliage plants for combination boxes or baskets.

21/4-inch pots.......\$12 per 100 3 -inch pots.......\$20 per 100

4 -inch pots.......\$30 per 100

7 -inch pots, made up, very

handsome ......\$2.50 each

8 -inch pots, made up, very handsome ......\$3.50 each

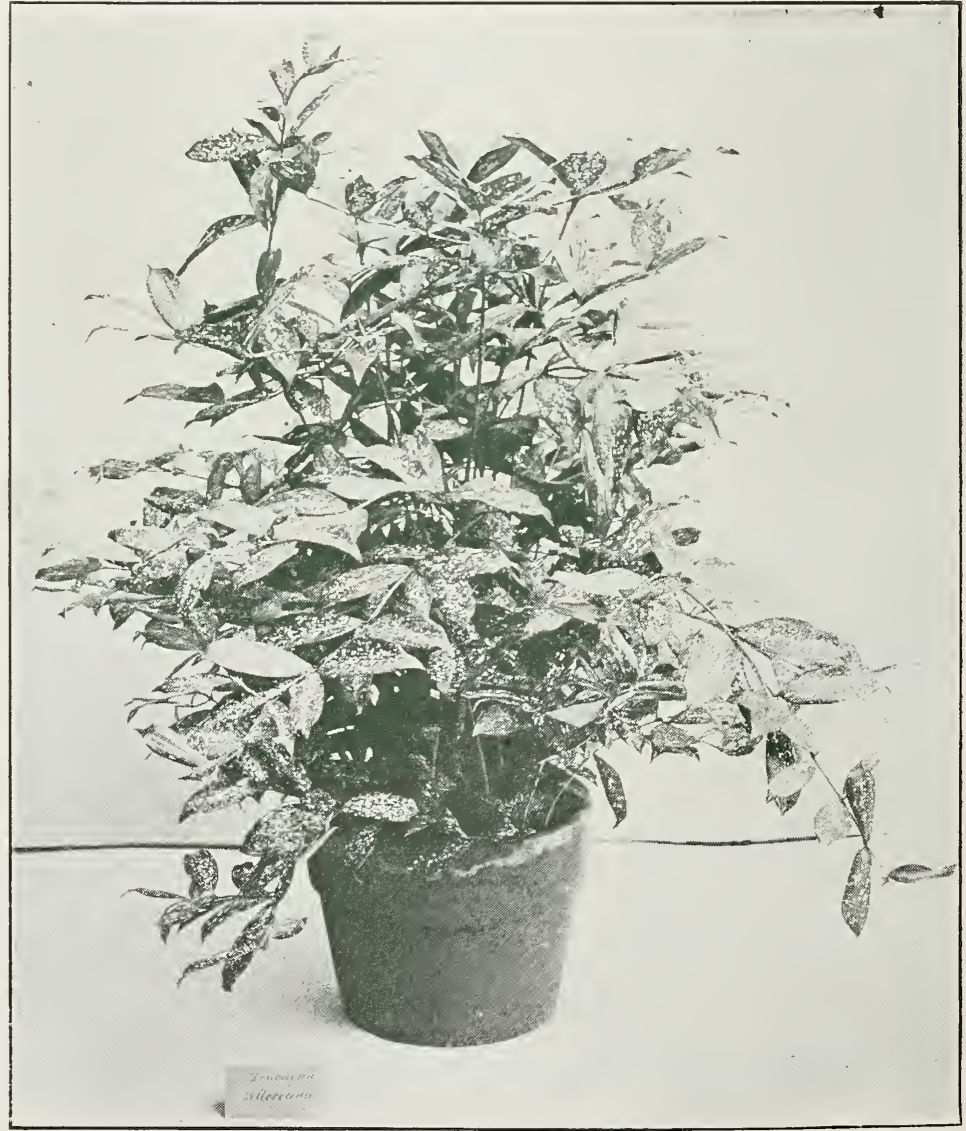

DRACAENA KELLERTANA (NEW) 


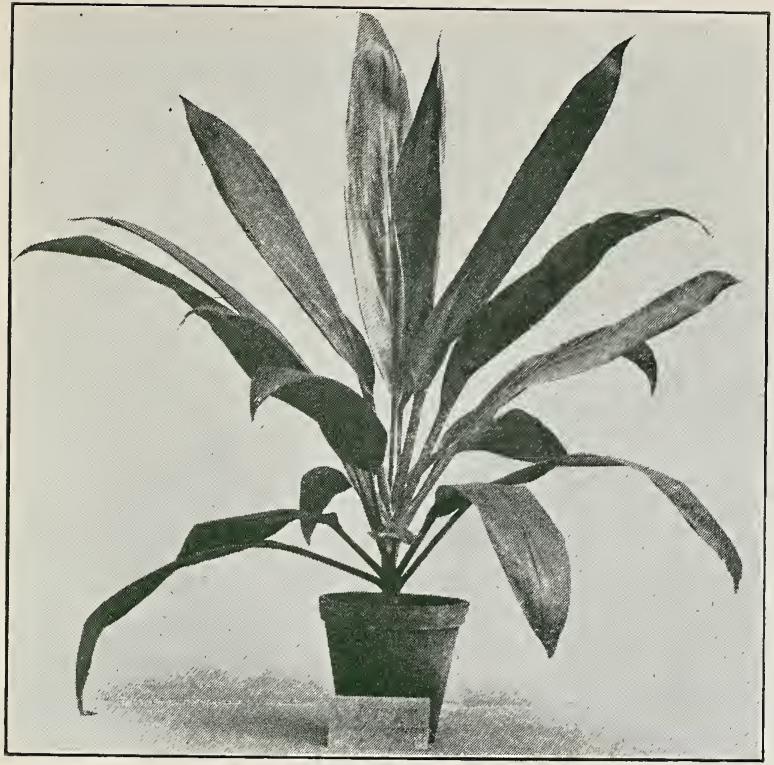

DRACAENA IMPERIALIS (RARE)

\section{DRACAENA SHEPHERDII}

Carmine and Green Leaves

3 -inch pots............... \$35 per 100 4 -inch pots. . . . . . . . . . . \$50 per 100 5-inch pots...............\$9 per doz. 6 -inch pots.........\$12, \$15 and $\$ 18$ per doz. 7 -inch pots, heavy .......\$2, $\$ 2.50$ and $\$ 3$ each

\section{DRACAENA ANERLEIENSIS (RARE)}

$21 / 4$-inch pots............... \$20 per 100

3 -inch pots..................\$35 per 100

4 -inch pots...............\$50 per 100

5 -inch pots............\$9 and $\$ 12$ per doz.

6 -inch pots.........\$15 and $\$ 18$ per doz.

\section{DRACAENA IMPERIALIS (RARE)}

One of the very best of the bright-colored varieties.

4 -inch pots............... \$50 per 100 5 -inch pots, heavy...........\$12 per doz. 6 -inch pots, heavy..........\$18 per doz.

\section{DRACAENA TERMINALIS}

\section{Exceptionally well colored}

$2 \frac{1}{4}$-inch pots, $\$ 10$ per $100 ; \$ 100$ per 1,000 3 -inch pots, $\$ 25$ per $100 ; \$ 225$ per 1,000 4 -inch pots, strong plants.. \$ $\$ 35$ per 100 5 -inch pots, strong plants,

$\$ 50$ and $\$ 75$ per 100

6 -inch pots, extra strong,

$\$ 12, \$ 15$ and $\$ 18$ per doz.

We would suggest ordering the above early, as the demand is always great.

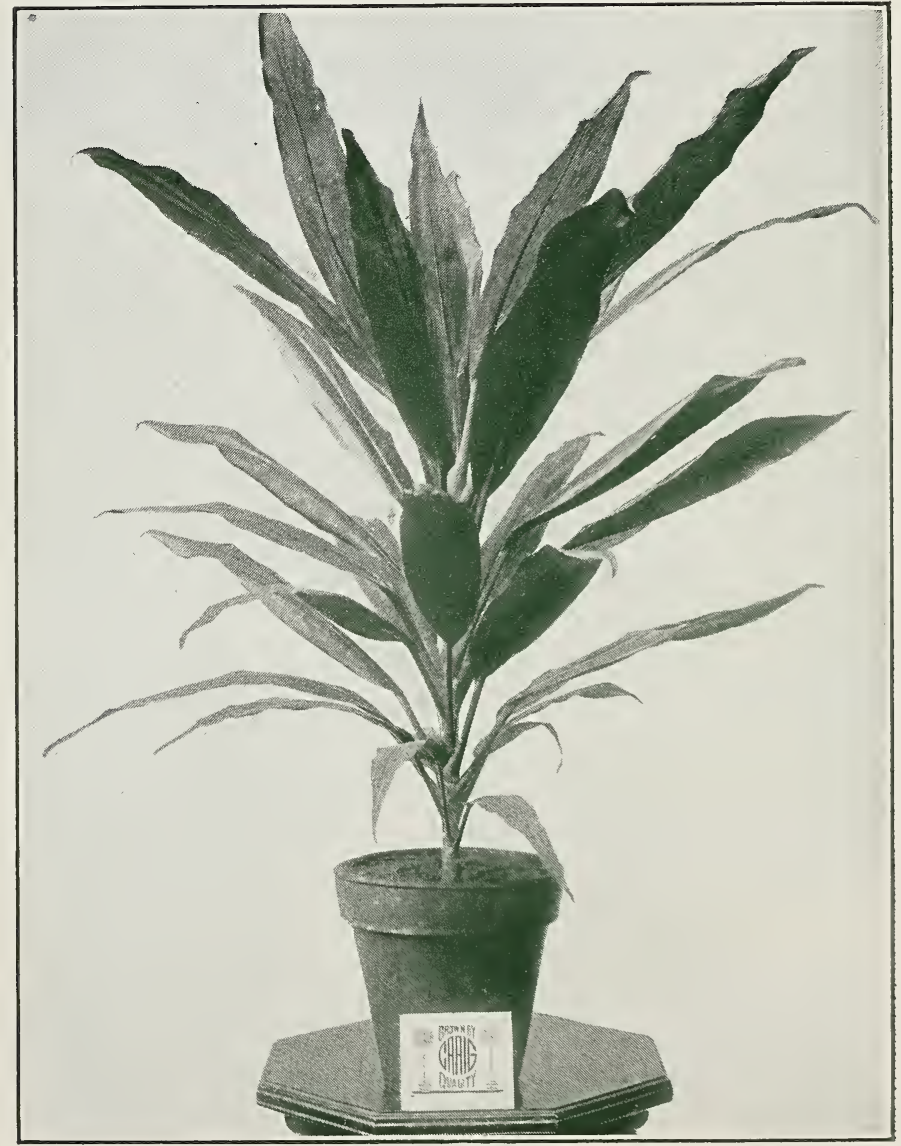

DRACAENA TERMINALIS 


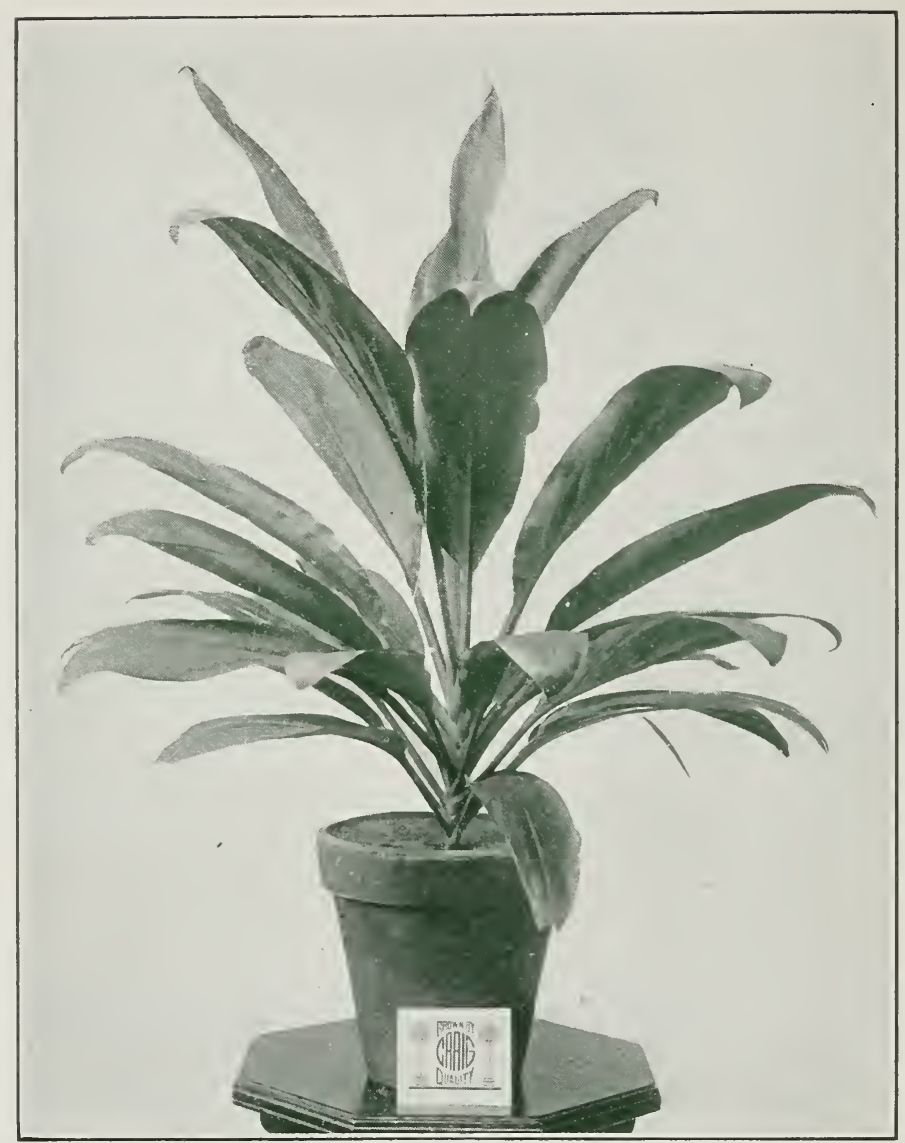

DRACAENA MANDATANA

DRACAENA MANDAIANA

Large, Bright=Red Leaf, Beautifully Colored

5 -inch pots...............\$75 per 100

6 -inch pots.........\$12, $\$ 15$ and $\$ 18$ per doz.

\section{DRACAENA DE SMETIANA}

This is one of the most desirable of the broad-leaf varieties; a strong, vigorous grower, with bold, dark green foliage which becomes beautifully suffused and variegated. Our stock is exceptionally fine this Fall. 4 -inch pots...............\$0.50 each 5 -inch pots.............. \$0.75 and $\$ 1$ each 6 -inch pots............ \$1.25 and $\$ 1.50$ each

\section{DRACAENA CRAIGII}

A seedling introduced by us in 1913. One of the rery best in commerce. Strong grower, fine habit, with foliage of light green, shading to beautiful pink. 4-inch pots................. $\$ 1$ each 6 -inch pots.......... $\$ 2.50$ and $\$ 3.50$ each

\section{DRACAENA GOLDIANA}

One of the best varieties. Always very searce. J-inch pots............... \$15 per doz.

\section{DRACAENA GLADSTONE (RARE)}




6 -inch pots.......... \$12, $\$ 15$ and $\$ 18$ per doz.

\section{DRACAENA GUILFOYLEII (RARE)}

4 -inch pots...............\$6 per doz. 5 -inch pots. . ..............\$9 per doz. 6 -inch pots.........\$12, $\$ 15$ and $\$ 18$ per doz.

\section{DRACAENA TITWORTHII (RARE)}

4 -inch pots...............\$6 per doz.

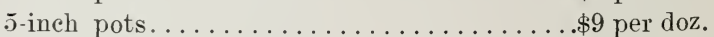
6 -inch pots...........\$12, \$15 and $\$ 18$ per doz.

\section{DRACAENA SUPERBUS}

An improved Lord Wolseley with narrow leaf. Bright red.

$21 / 4$-inch pots................ \$20 per 100

3 -inch pots...............\$35 per 100

4 -inch pots...............\$50 per 100 


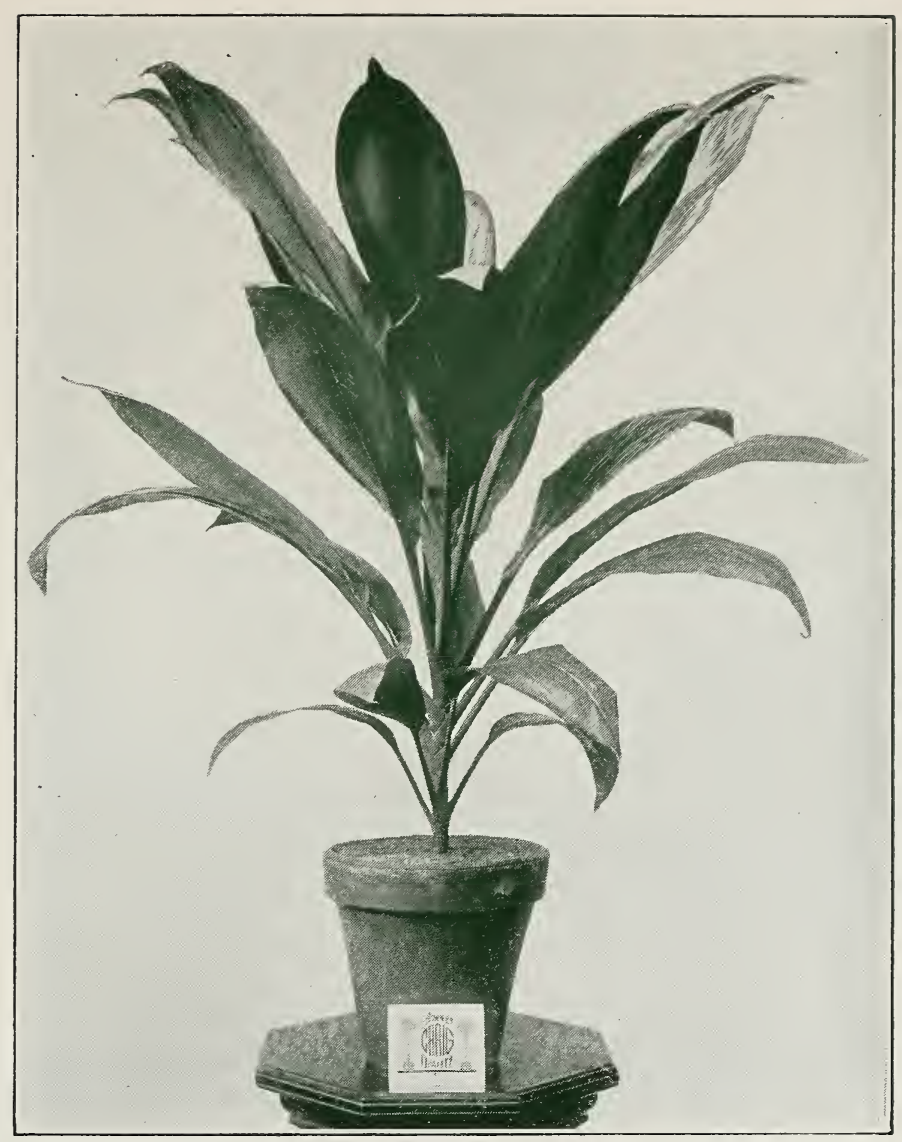

DRACAENA DE SMETIANA

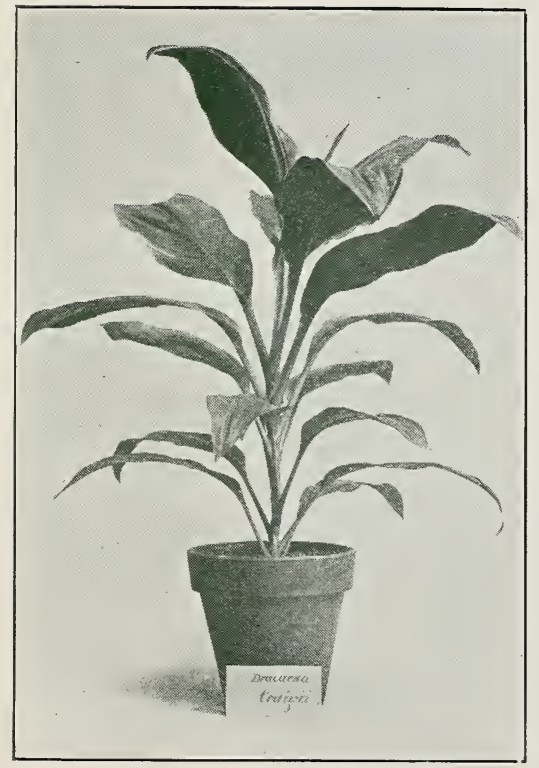

\section{DRACAENA MARGUERITE STORY}

Strong grower and wonderful habit. Dark green shading to orange and pink.

$21 / 4$-inch pots.................... $\$ 20$ per 100

3 -inch pots................... \$35 per 100

4 -inch pots................... \$50 per 100

Specimens ................. $1, \$ 1.50$ and $\$ 2$ each

\section{DRACAENA SEEDLINGS}

Some beautiful varieties in many colors.

4 -inch pots..................... \$2 and $\$ 5$ each 


\section{BEGONIAS}

We desire to call the attention of prospective buyers to Begonia Glorie de Lorraine and Begonia Lonsdale.

Begonias have been one of our specialties for years. This year we are growing more Begonias than ever before, being teh largest Begonia growers in the world of the following varieties. This branch of our business has been built up on the quality of the goods we have delivered to our customers. We desire that each and ererr Begonia grower send us his order, or at least a share of it, for comparison's sake.



BEGONIA GLORY OF CINCINNATI

\section{BEGONIA GLORIE DE LORRAINE}

$21 / 2$-inch pots............... $\$ 15$ per $100 ; \$ 135$ per 1,000

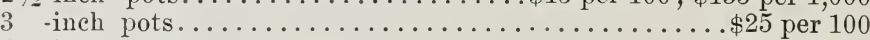

4 -inch pots $\$ 35$ per 100

5 -inch pots-Ready September 1 st........... \$50 per 100

6 -inch pots-Ready October 1 st.............\$75 per 100

\section{BEGONIA GLORY OF CINCINNATI}

This variety is endorsed by all of the leading retail florists. It will hold the flowers much better than the Begonia Glorie de Lorraine.

$21 / 2$-inch pots...............\$20 per $100 ; \$ 175$ per 1,000

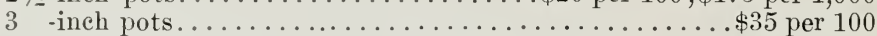

4 -inch pots, heary................... \$50 per 100

\section{BEGONIA KONKURENT \\ A Greatly Improved Begonia Cincinnati}

The above variety is a German introduction, and we have tried it for three years. It makes a much better shaped plant than Cincinnati, is freer flowering, more shapely, and next to Norwood, is the best keeping Begonia we have ever handled, the original flowers remaining on the plants for several months.

$21 / 4$-inch pots................ \$30 per $100 ; \$ 250$ per 1,000

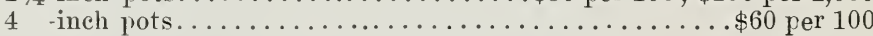

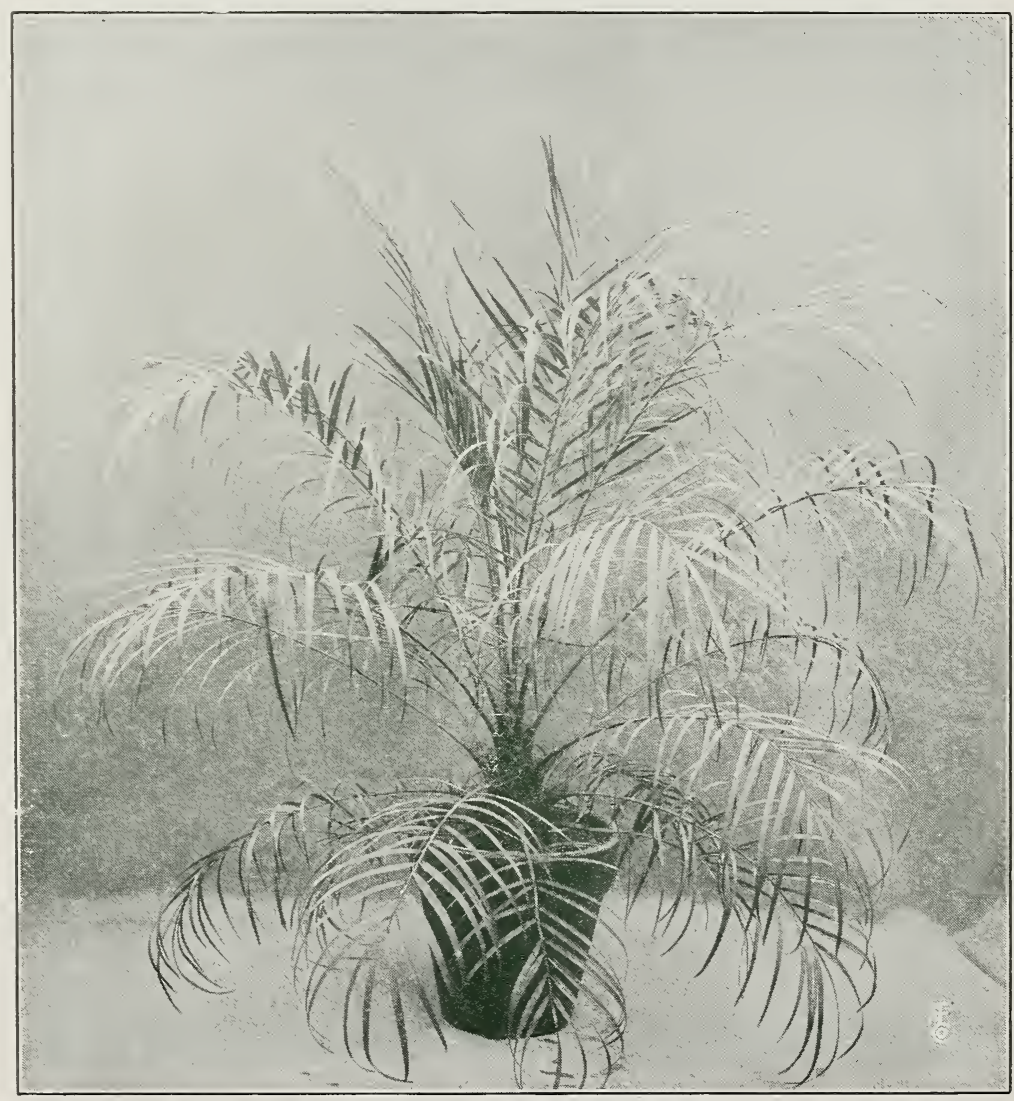

PHOENIX ROEBELENII 


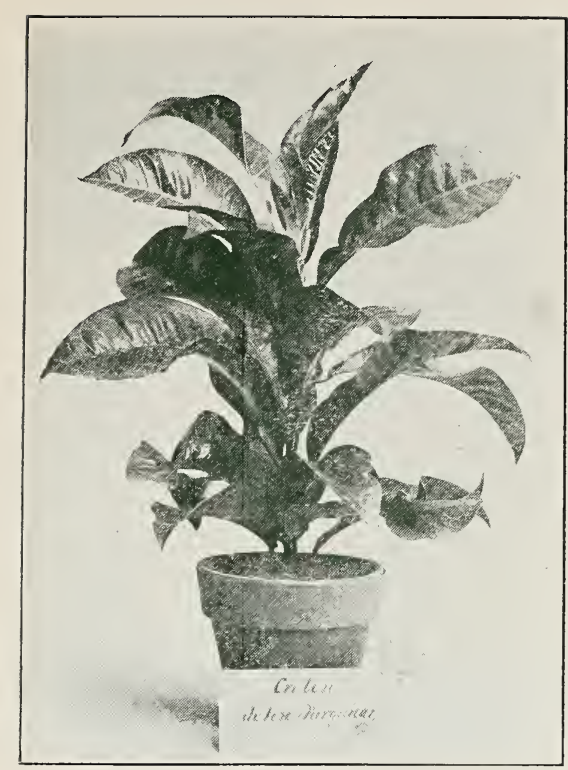

\section{NEW SEEDLING CROTON JOHN FARQUHAR}

\section{PHOENIX ROEBELENII}

This is unquestionably one of the great palms of the future, combining the grace of a Cocos Weddelliana with the hardiness of a Kentia. It will prove an invaluable plant for the house.

12-inch tubs, specimen plants,

$\$ 10, \$ 12.50, \$ 15$ and $\$ 20$ each

\section{BEGONIA LONSDALE}

We have a very large stock of this light sport at the same prices as quoted for Begonia Glorie de Lorraine. This variety is considered far superior to the original type, making a finer shaped plant and holding the flowers much better. The color is a little lighter than the original Begonia Glorie de Lorraine.

\section{BEGONIA FLORENCE DAVENPORT Introduced June, 1914}

This variety we believe will displace Begonia Cincinnati. It is a great improvement over Cincinnatifreer flowering, more symmetrical and holds its flowers much longer.

$21 / 2$-inch pots................. \$25 per 100 4 -inch pots............... \$50 per 100

\section{ARECA LURESCENS}

Perfect plants with rich, dark-green foliage. Our stock has been grown cool and hard. It is in splendid condition and will surely give satisfaction. Large sizes very scarce this year.

4-inch pots, made up.............\$25 per 100 6 -inch pots, made up, 26 to 28 inches tall,

$\$ 12$ per doz.; $\$ 90$ per 100

7 -inch pots, made up, very heavy, 36 inches

tall .............. $\$ 2, \$ 2.50$ and $\$ 3$ each

6 -inch pots, extra heavy. $\$ 15$ per doz.; $\$ 110$ per 100

8 -inch pots, extra heavy, 36 to 42 inches

tall .............. \$3, $\$ 3.50$ and $\$ 4$ each

13-inch tubs, made up, very heavy, 7 to 8

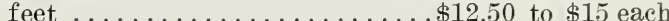

\section{PANDANUS VEITCHII}

Well-colored plants. Large stock.

$21 / 2$-inch and 3 -inch pots............\$30 per 100

4 -inch pots........... \$6 per doz.; $\$ 45$ per 100

5 -inch pots............\$9 per doz.; $\$ 70$ per 100

6 -inch pots...........\$12 per doz.; $\$ 90$ per 100

8 -inch pots...............\$30 per doz.

Large specimens...........\$3, $\$ 4$ and $\$ 5$ each



PANDANUS VEITCHII 


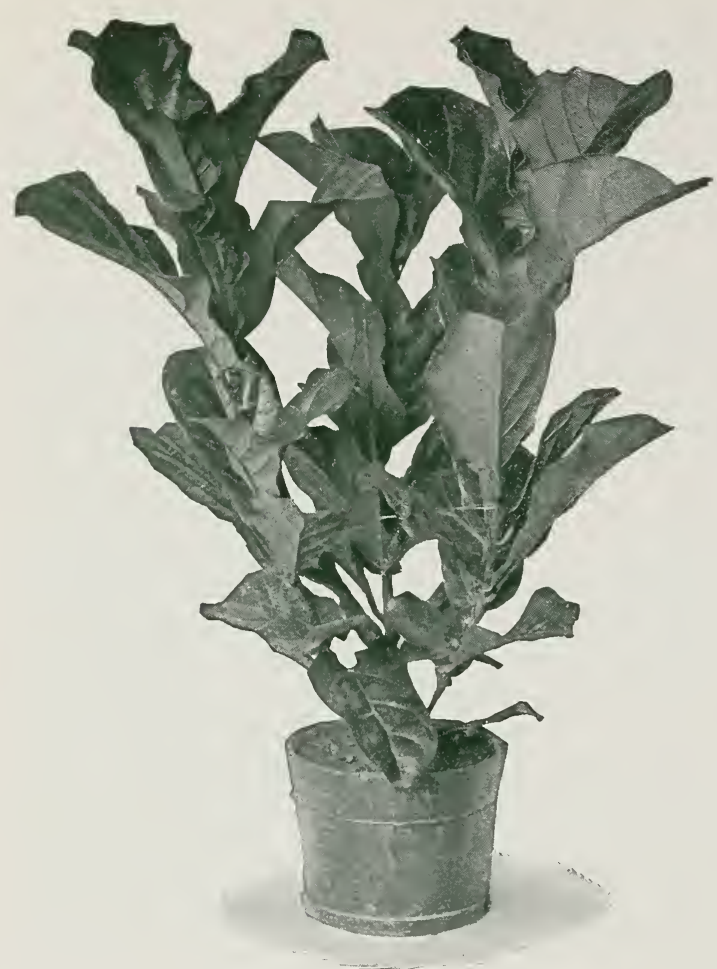

FICUS PANDURATA

FICUS PANDURATA

The plant of the century. Positively the best house and porch plant to date. Our stock of this wonderful plant this year is finer than we have heretofore offered. It will surely give satisfaction.

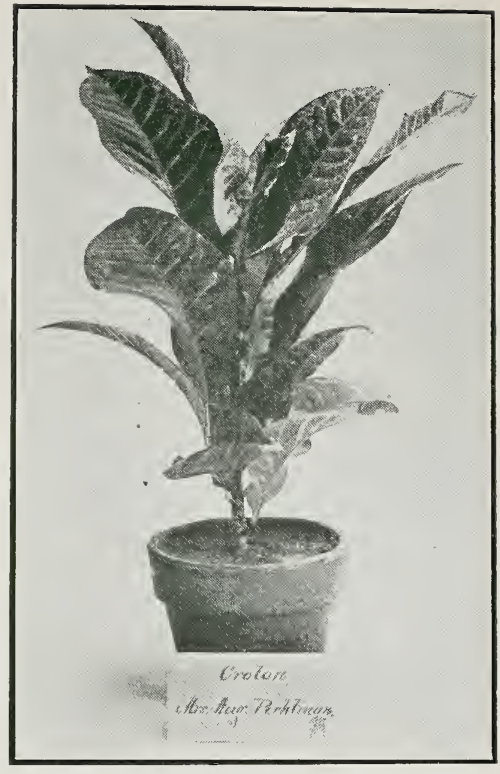

NEW SEEDLING CROTON AUGUST POEHLMANN

6 -inch pots, 2 feet tall.

.$\$ 2$ each

7 -inch pots, 3 feet tall............\$2.50 each

8-inch pots, 4 feet tall.............\$3 each

10 -inch and 11 -inch tubs, 5 feet to 10 feet

tall............\$4, $\$ 5, \$ 6$ and $\$ 7.50$ each Branch plants, exceptionally fine,

$\$ 2.50, \$ 3, \$ 3.50, \$ 4$ and $\$ 5$ each

The large plants are unusually fine.

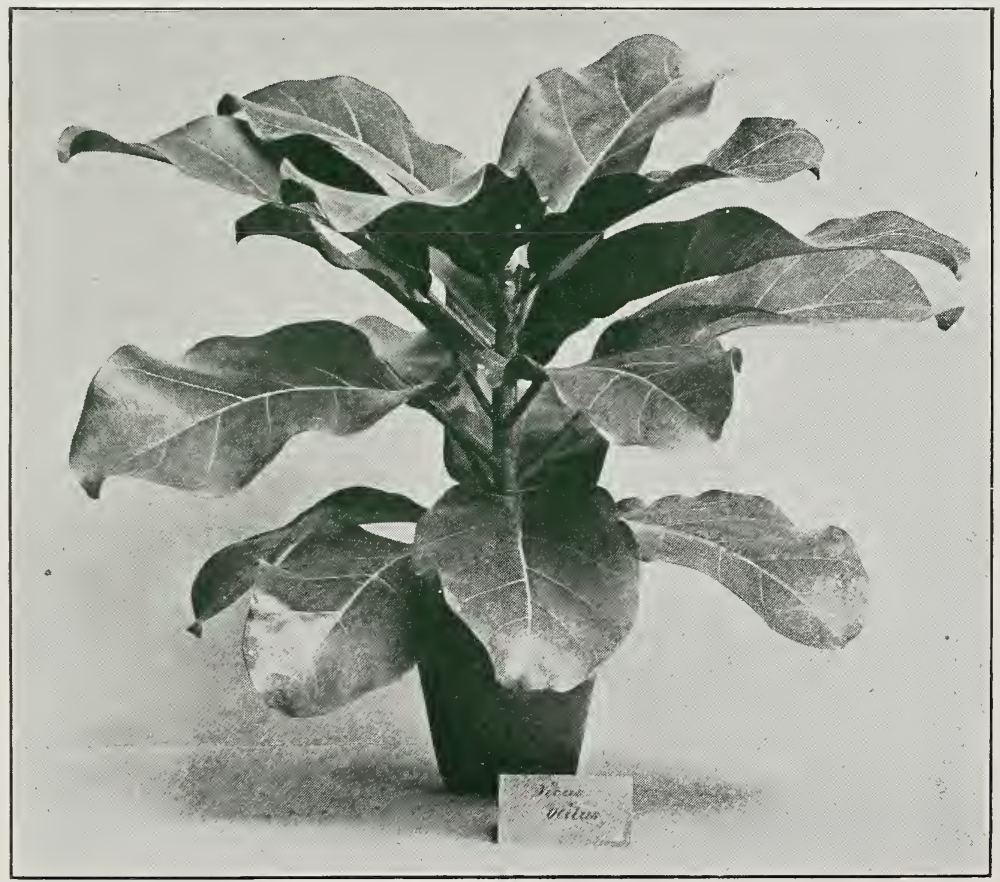

FICUS UTILUS 


\section{BOXWOOD}

We will have an unusually large stock of Boxwood to offer for delivery October 1st. The plants will be in all sizes from the small window box size to the large pyramids 5 feet and 6 feet tall. Write us early regarding our Boxwood. We will send you our lowest quotations.

\section{FICUS UTILUS}

A species that came to us through the Botanical Gardens at Washington, D. C., which promises to be a valuable addition as a decorative house plant. The leaves are thick and leathery, and are from 18 inches to 24 inches long, one half as wide; of a rich, hollygreen color, with midrib and reins of an ivory white which stand out prominently.

6 -inch pots, 24 inches tall............\$2 each 6 -inch pots, 30 inches tall..........\$2.50 each 7 -inch pots, 36 inches tall...........\$3 each 8 -inch pots, 48 inches tall........\$t and $\$ 5$ each 11 -inch pots, 6 to 7 feet tall.....\$6 and $\$ 7.50$ each

\section{FICUS CRAIGII}

This variety is a greatly improved Ficus Elastica and is bound to prove $\imath$ universal favorite. It is close jointed and the midrib stands out prominently, being ivory-white in color.

4 -inch pots, 15 inches tall. . . . . . . . \$35 per 100 6 -inch pots, 18 to 24 inches tall....\$5 and $\$ 9$ per doz.

\section{CYCAS REVOLUTA LEAVES}

We have on hand large specimen plants of Cycas Revoluta from which we cut the leaves. The natural leaves are far superior to the prepared Southern-grown stock and are being used more each year for the better work by retail florists. We can supply perfect leares at all times.

Leaves, 36 inches to 42 inches long.

$\$ 2.50$ and $\$ 3$ per pair Specimen plants, in tubs. $\$ 20, \$ 25, \$ 35$ and $\$ 50$ each

\section{CYCLAMEN}

This has been one of our specialties for orer twenty years. This year we grew upwards of 125,000 plants. In all of our experience we have never seen a finer lot of plants. We are growing our stock in new houses. They are absolutely elean and perfect in every way and not to be compared with weakly-drawn stock offered at less money.

$21 / 2$-inch pots.........\$8 per $100 ; \$ 75$ per 1,000

4 -inch pots........\$25 per $100 ; \$ 225$ per 1,000

5 -inch pots........ $\$ 50$ per $100 ; \$ 450$ per 1,000

6 -inch pots..........\$75 and $\$ 100$ per 100

7 -inch pots.............\$150 per 100

This will be profitable to anyone buying now.

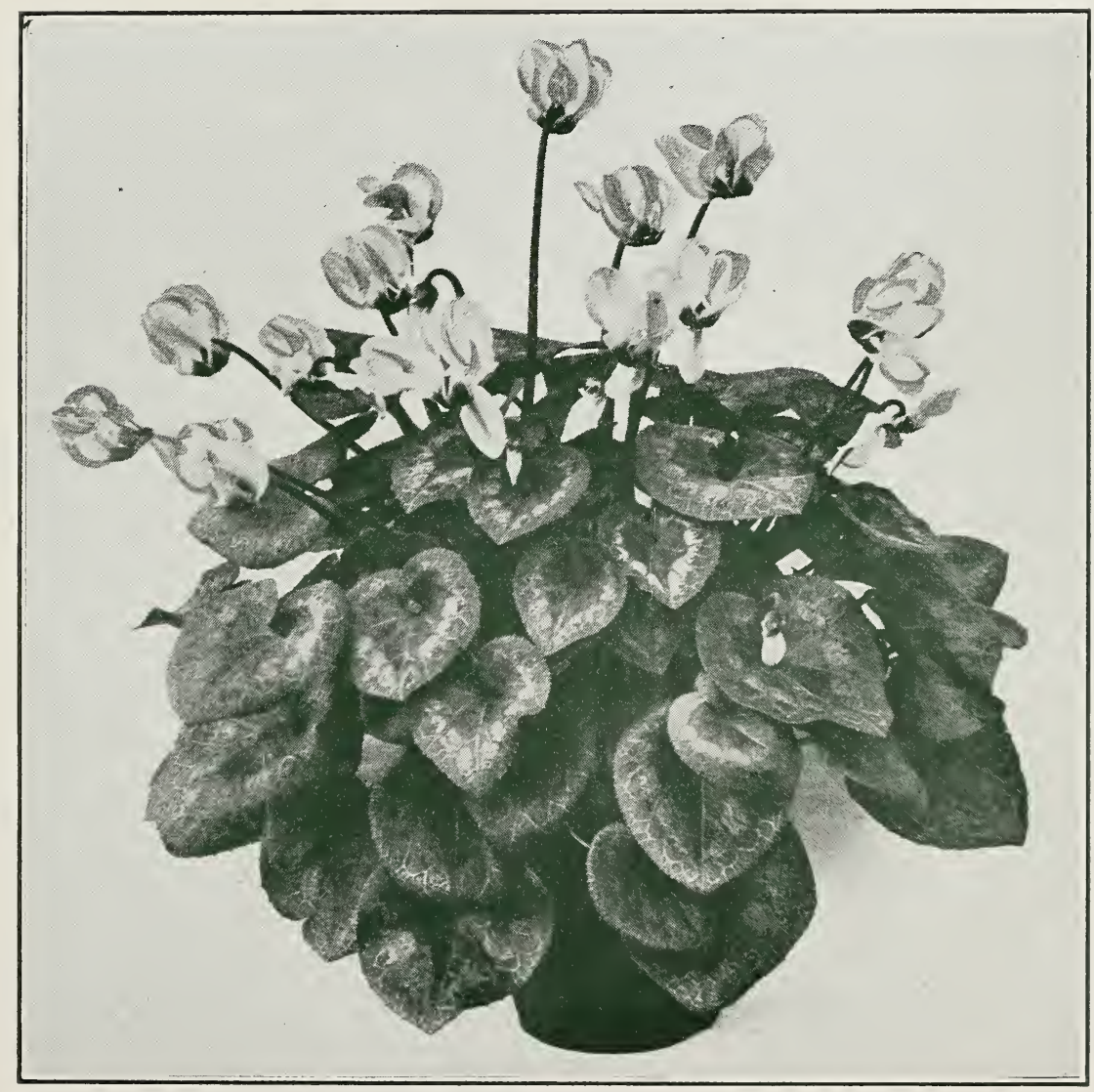

CYCLAMEN 
GARDENIA VEITCHII

21-inch pots-January 1st-Delivery,

$\$ 7$ per $100 ; \$ 60$ per 1,000

4 -inch pots, rery heary. Ready now,

$\$ 20$ per $100 ; \$ 175$ per 1,000

6 -inch pots, very heary, will flower early,

$\$ 6, \$ 9$ and $\$ 12$ per doz.

Our stock is unusually large and exceptionally fine.

\section{GENISTA RACEMOSA}

A large stock of well-grown plants for growing on. 4 -inch pots, heary . . . . $\$ 20$ per $100 ; \$ 175$ per 1,000 5 -inch pots, hearr...... $\$ 3$ 5 per $100 ; \$ 300$ per 1,000 6 -inch pots, heary...... $\$ 50$ per $100 ; \$ 400$ per 1,000 7 -inch pots, heary. . . . . . . . . . $\$ 75$ per 100 Larger plants............... $\$ 1$ and $\$ 3$ each

\section{HYDRANGEAS}

The new French Hydrangeas. All of the varieties here offered have been tested by us under ordinary conditions as to their adaptability to forcing for Easter. All have proven themselves to be valuable additions. We have over 40,000 strong plants in the following rarieties:

\section{FRENCH HYDRANGEA}

Radiant; Bouquet Rose, bright pink; Gene de Vibrare, bright rose; La Lorraine, bright pink; Mme. A. Riveram, bright rose; Mme. E. Mouillere, best white; Mme. Maurice Hawar, bright pink; MIme. Renee Gaillard, large white; Radiant, deep pink.

4 -inch pots, heary...... $\$ 20$ per $100 ; \$ 180$ per 1,000 6 -inch pots, heary......... $\$ 35$ and $\$ 50$ per 100 Larger plants........\$0.75, $\$ 1, \$ 1.50$ and $\$ 2$ each

\section{HYDRANGEA OTASKA}

Pot-grown stock; well-ripened plants. 4-inch pots, strong. . . . . . . . . . \$15 per 100 6 -inch pots, strong, 4 to 6 heads... $\$ 25$ and $\$ 35$ per 100 6-inch pots, strong, 6 to 7 heads... $\$ 10$ and $\$ 50$ per 100 Larger plants. . \$0.75, \$1, \$1.25, \$1.50, \$2 and \$3 each Order at once to insure an early start.

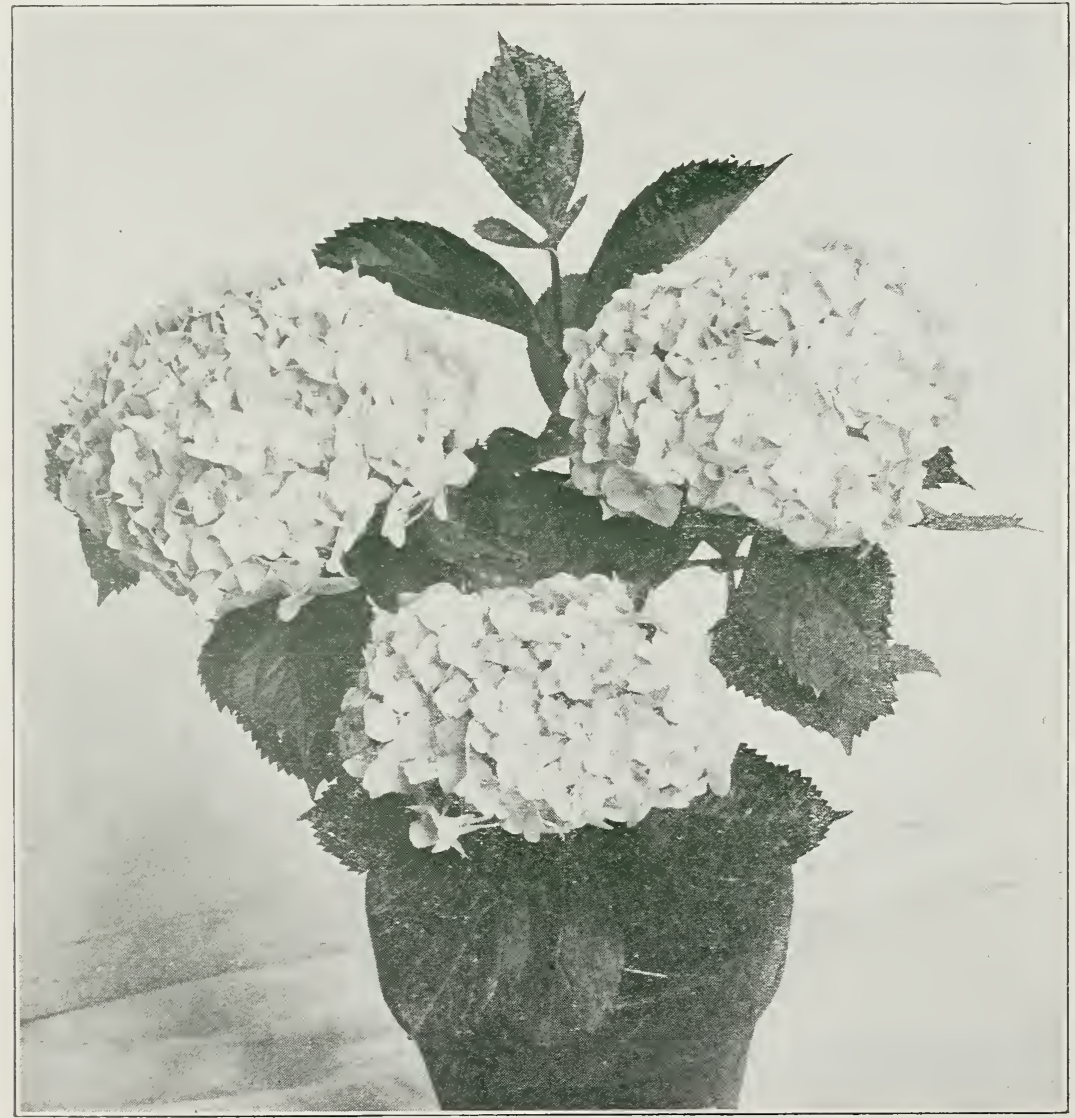

FRENCH HYDRANGEA 


\section{ROSES}

We have an unusually large stock of extra-strong pot grown plants in both the Hybrids and Climbers, which is much better than field grown plants for forcing. Place orders early. We will reserve and ship when you want them.

Baby Ramblers, 6-inch pots......... $\$ 30$ per 100

Phyllis, 6-inch pots...............\$30 per 100

Orleans, 6 -inch pots............\$30 per 100

Tausendschon, 6-inch pots.......\$35 and $\$ 50$ per 100

Tausendschon, larger specimens,

Juniata, specimens, 7 -inch rots,

$\$ 0.75, \$ 1$ and $\$ 1.50$ each

$\$ 0.75, \$ 1$ and $\$ 1.50$ each

\section{PIONSETTIA}

The true, red variety. Stock of the highest quality. $21 / 1$-inch pots...........\$7 per $100 ; \$ 60$ per 1,000

3 -inch pots, heavy.......\$15 per $100 ; \$ 125$ per 1,000

4 -inch pots, heavy........\$25 per $100 ; \$ 225$ per 1,000

\section{PANDANUS UTILUS}

A very fine stock of this variety in the following sizes.

4-inch pots. . . . . . . . . . . . . . . . \$25 per 100

5 -inch pots..................\$50 per 100

6 -inch pots, heavy.............\$75 per 100

\section{OTAHEITE ORANGES}

A very fine stock of this wonderful Christmas plant. Plants with 8 to 50 fruit, delivery September,

15 cents per fruit Plants, well ripened, delivery December 1st,

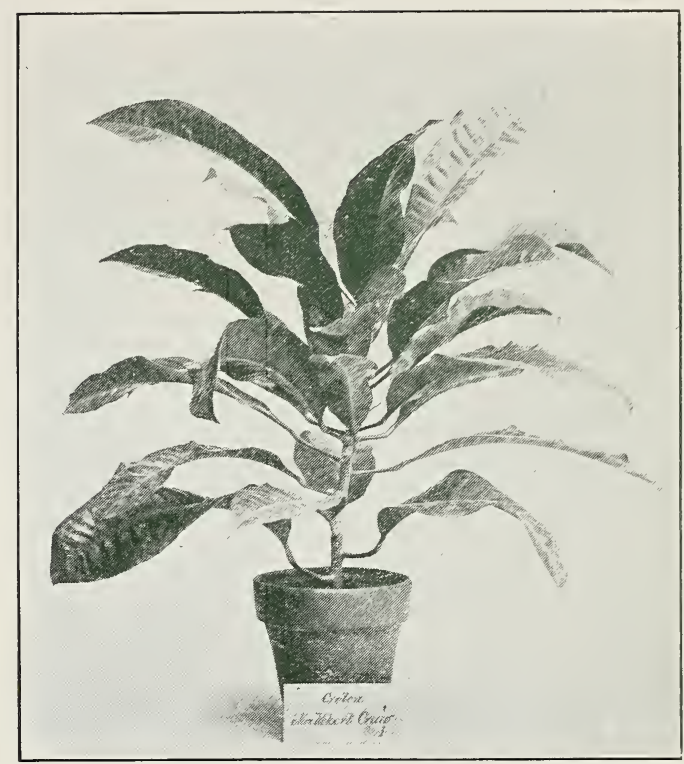

NEW SEEDLING CROTON MRS. ROBT. CRAIG

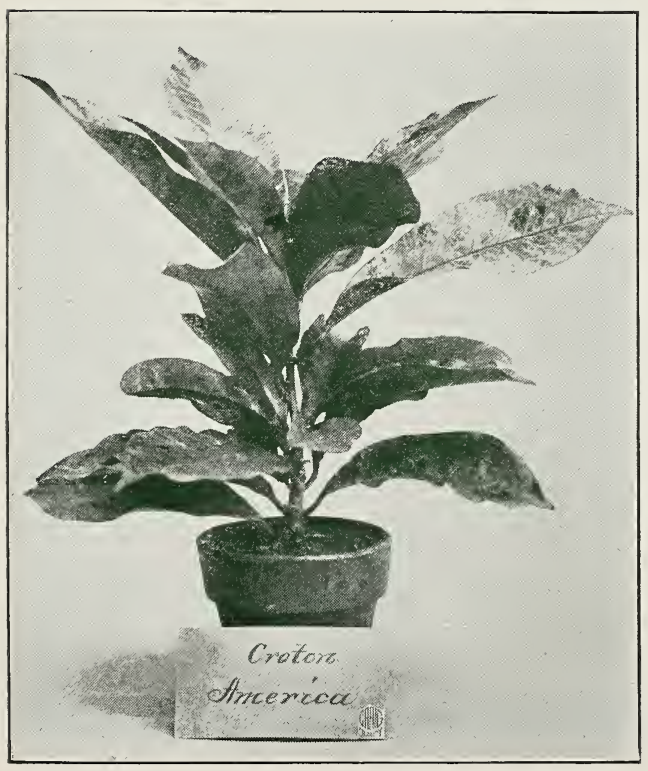

NEW SEEDLING CROTON AMERICA

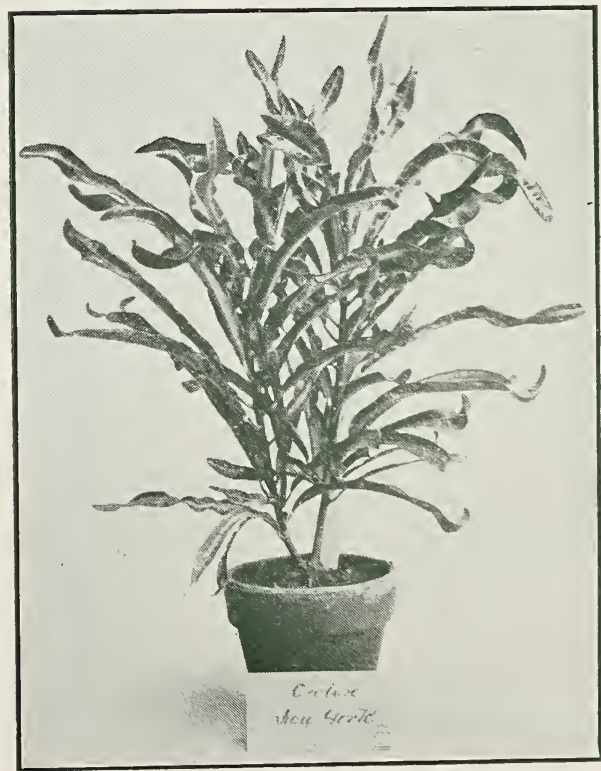

CROTON NEW YORK 


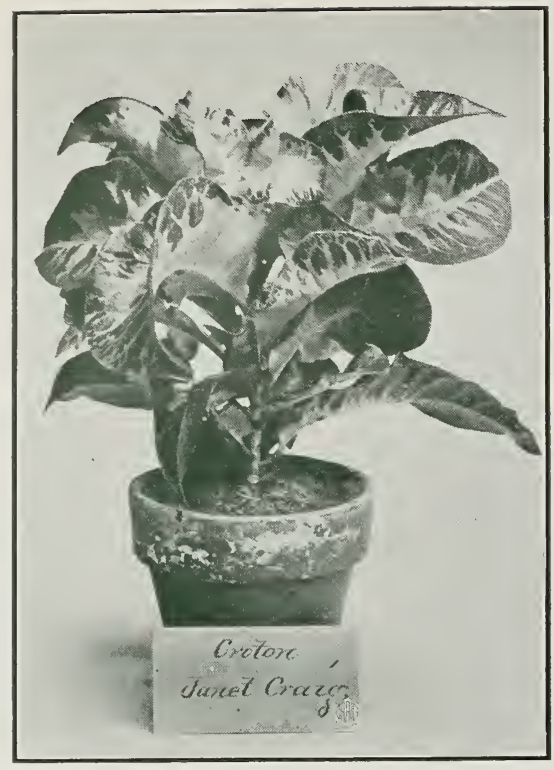

NEW SEEDLING CROTON JANET CRAIG



CROTON GEM

\section{0,000 NEPHROLEPIS (in variety)}

We are the largest growers of Nephrolepis Ferns in the country in the following varieties; in fact, we are the headquarters for them. The demand increases each year, and it is our aim to have every variety of Nephrolepis, in every size, every day in the year.

\section{NEW NEPHROLEPIS-JOHN WANAMAKER} "THE WANAMAKER BOSTON FERN"

We will introduce the above fern in August, 1915. In presenting this fern to the trade, we feel confident that it will make a place for itself.

A "sport', from Nephrolepis Scholzelii, with longer, narrower, gracefully drooping fronds. It is not so compact in growth as Scholzelii, and therefore, does not decay in the center, and is a durable house fern. It is a rapid grower, making an abundance of fronds, and is quite distinct from any other Nephrolepis.

Strong plants from 21/4-inch pots-for delivery in August. $\$ 3$ per doz.; $\$ 20$ per $100 ; \$ 150$ per 1,000 .

The following ready for delivery October 1 st: 4 -inch pots, $\$ 50$ per $100 ; 6$-inch pots, $\$ 1$ each; 8-inch pots, $\$ 2$ each. Specimens in tubs, $\$ 3.50$ and $\$ 5$ each.

\section{NEPHROLEPIS TODEAOIDES}

London Fern. A good, strong grower and one we think of very highly.

$21 / 4$-inch pots.........\$6 per $100 ; \$ 50$ per 1,000

4 -inch pots........\$20 per $100 ; \$ 180$ per 1,000

6 -inch pots.............. \$6 per doz.

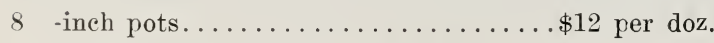

9 -inch and 10-inch tubs...\$24, $\$ 30$ and $\$ 36$ per doz.

\section{NEPHROLEPIS ELEGANTISSIMA IMPROVED}

This variety is a greatly improved Elegantissima and shows no tendency to revert to the Boston. This will prove a valuable addition to the crested varieties. $21 / 4$-inch pots. . . . . . $\$ 5$ per $100 ; \$ 50$ per 1,000 4 -inch pots..............\$20 per 100 6 -inch pots................\$6 per doz. 8 -inch pots.......... $\$ 12$ and $\$ 15$ per doz. Larger plants........\$2, $\$ 2.50, \$ 3$ and $\$ 3.50$ each 




NEPHROLEPIS ELEGANTISSIMA IMPROVED

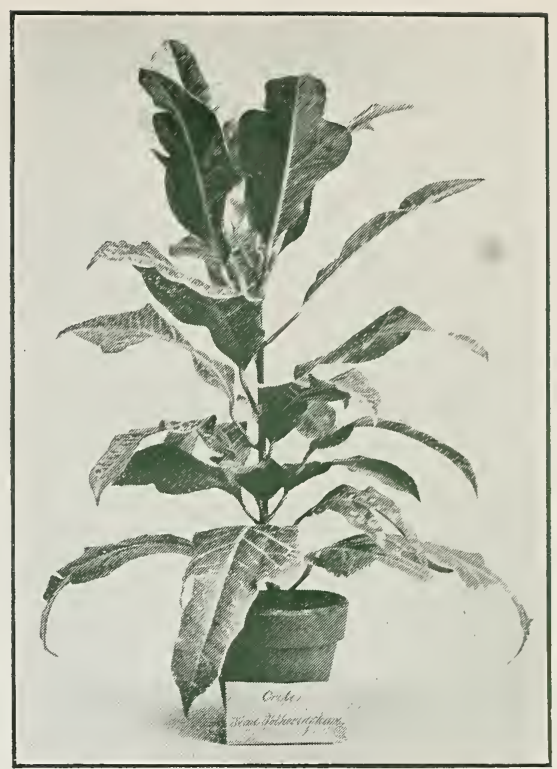

NEW SEEDLING CROTON

JEAN FOTHERINGHAM

\section{NEPHROLEPIS SCHOLZELII}

This is an ideal crested Fern, holding the same relation to all other erested varieties that the Scottii holds to the old Boston.

$21 / 1$-inch pots. . . . . . $\$ 6$ per $100 ; \$ 50$ per 1,000 4 -inch pots, heavy . . . . \$20 per $100 ; \$ 180$ per 1,000

6 -inch pots, heavy...... \$6 per doz.; \$45 per 100 6 -inch pots, heavy. . . . . \$9 per doz.; $\$ 70$ per 100

8 -inch, $\%$-pots........\$12 per doz.; $\$ 90$ per 100 11 -inch tubs...........\$24 and $\$ 30$ per doz.

\section{NEPHROLEPIS ELEGANTISSIMA COMPACTA}

A dwarf, compact form of Nephrolepis Elegantissima, each plant making an ideal shape.

$21 / 4$-inch pots . . . . . . $\$ 6$ per $100 ; \$ 50$ per 1,000

4 -inch pots...............\$20 per 100

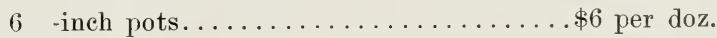

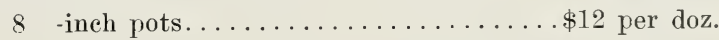

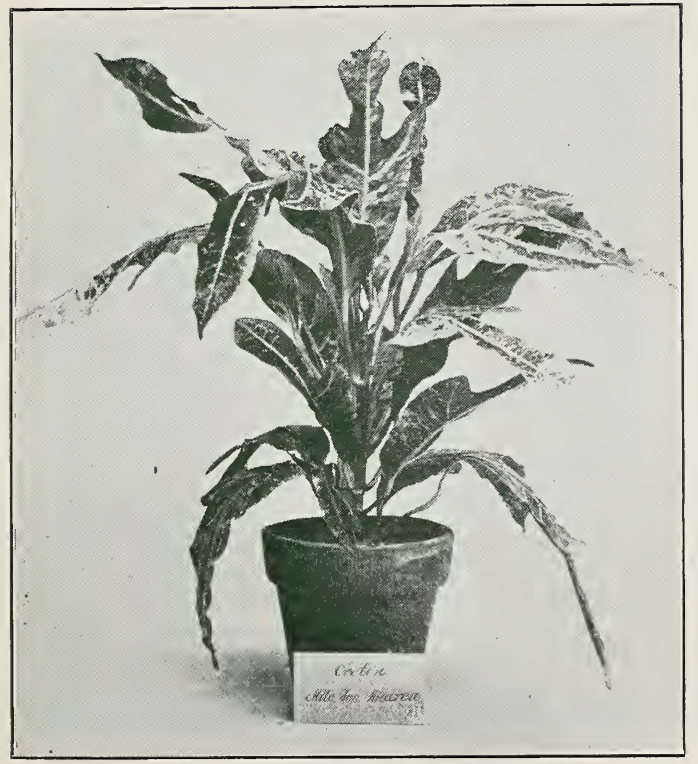

CROTON MLLE. JOSEPHINE ANDREA

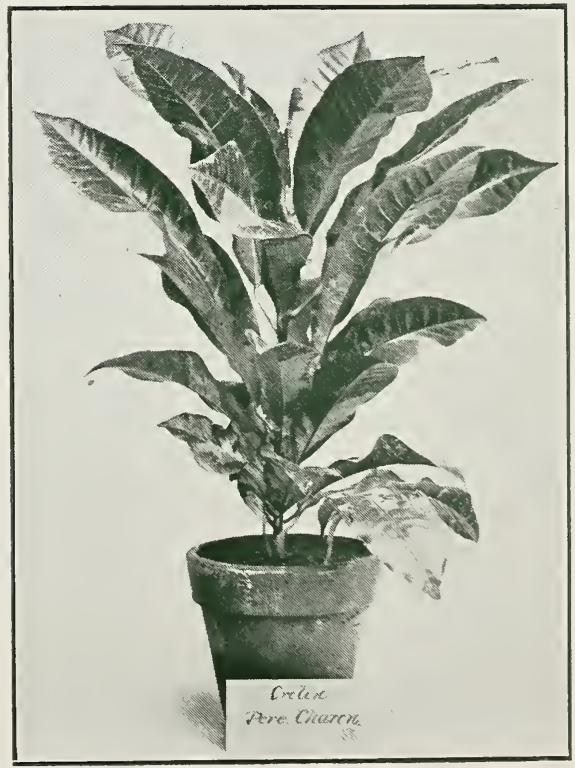

CROTON PERE CHARON 


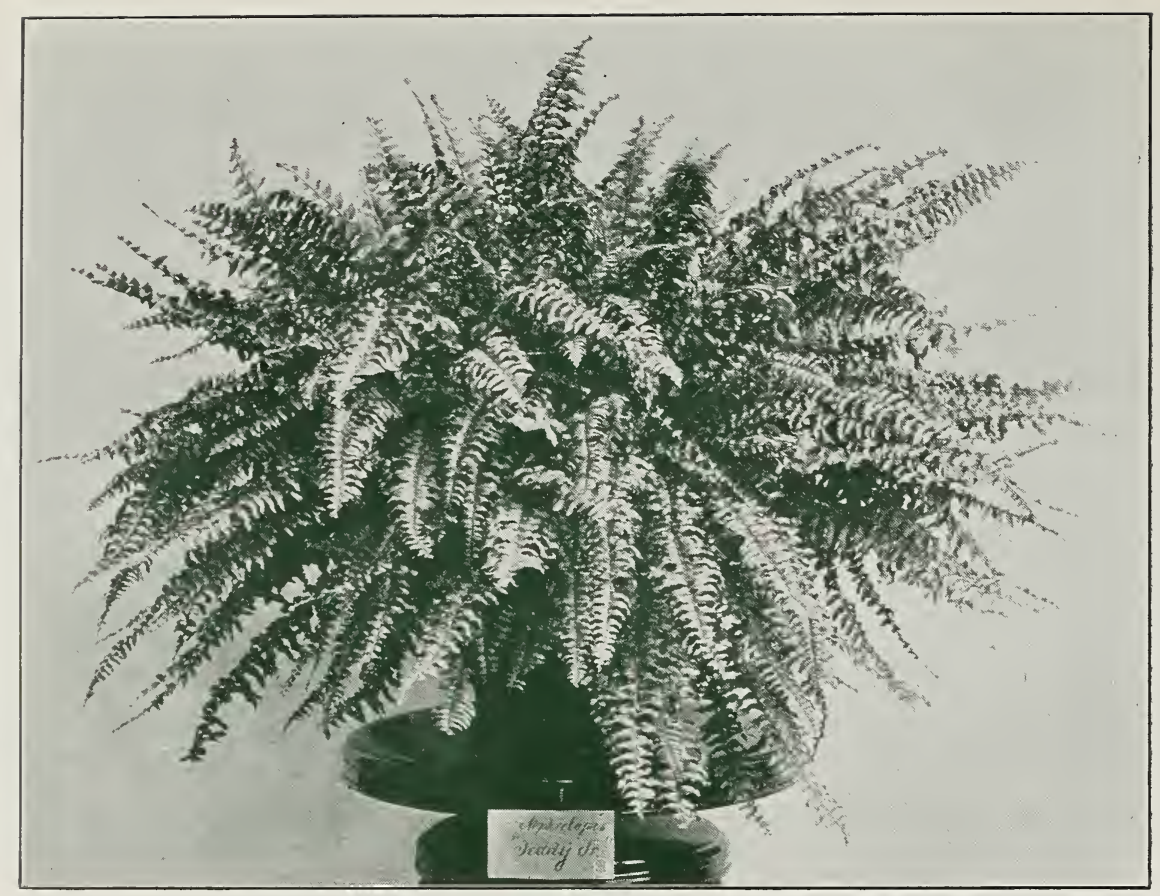

"TEDDY JUNIOR"

\section{"TEDDY JUNIOR"}

\section{A Grand New Dwarf Fern}

Fine, young plants from 21/4-inch pots,

$\$ 7$ per $100 ; \$ 60$ per 1,000

4-inch pots, heary.........\$20 per 100; $\$ 180$ per 1,000

6 -inch pots, heary................\$50 per 100

6 -inch pots, very heary.............\$75 per 100

8 -inch pots, very heary.............\$15 per doz.

11-inch tubs..............\$2, \$2.50 and $\$ 3$ each

\section{NEPHROLEPIS ROBUSTA (NEW)}

Place orders at once for Nephrolepis Robusta. The Silver Medal Fern at the National Flower Show, winning over all competition. We claim this variety to be the finest of all crested Nephrolepis, being exceptionally fine in large sizes. It is the strongest grower of all the Nephrolepis Ferns, never reverts and every plant is symmetrical and salable in all sizes.

$21 / 4$-inch pots, strong plants....\$8 per $100 ; \$ 75$ per 1,000

4 -inch pots, strong plants... \$25 per $100 ; \$ 200$ per 1,000

6 -inch pots, strong plants.......\$50 and $\$ 75$ per 100

8 -inch Azalea pots, heavy plants....\$12 and \$15 per doz.

11 -inch tubs, heavy plants.......\$2, $\$ 2.50$ and $\$ 3$ each

\section{NEPHROLEPIS SCOTTII}

Our stock is in superb condition.

$21 / 4$-inch pots. . . . . \$5 per $100 ; \$ 45$ per 1,000

4 -inch pots....\$20 per $100 ; \$ 180$ per 1,000

6 -inch pots.......\$6 per doz.; $\$ 45$ per 100

6 -inch pots, heavy. $\$ 9$ per doz.; $\$ 70$ per 100

8 -inch $3 / 4$ pots.... \$12 per doz.; $\$ 90$ per 100

10 -inch $3 / 4$ pots............\$18 per doz.

11 -inch tubs.......\$2, \$2.50 and $\$ 3$ each



CROTON MONS. KOHL 


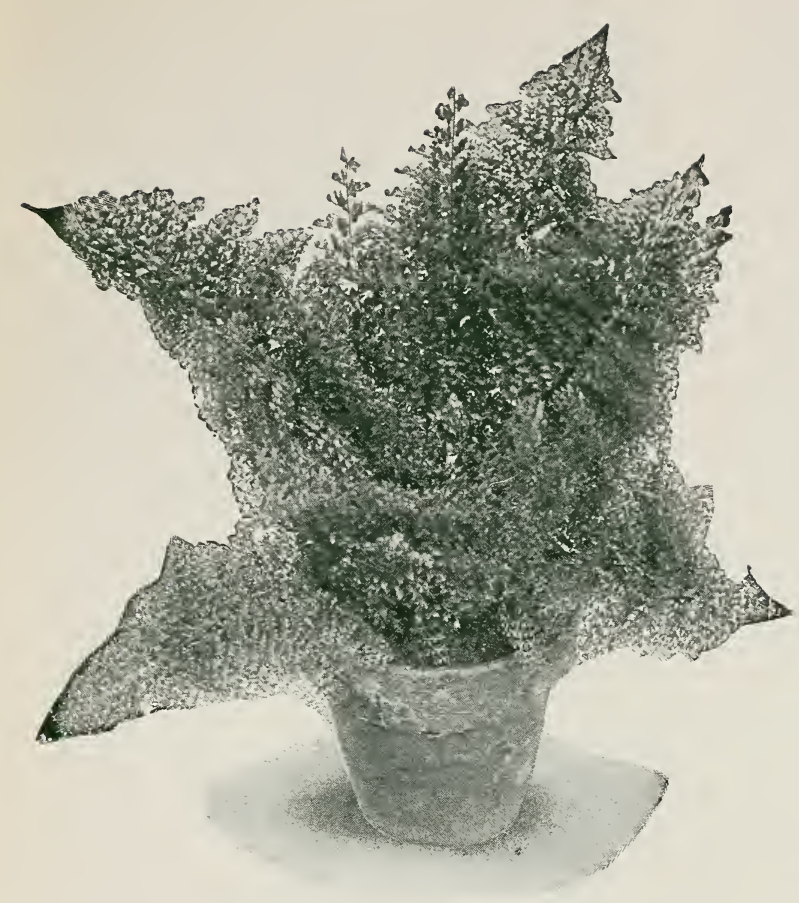

NEPHROLEPIS SMITHII

\section{NEPHROLEPIS SMITHII}

The greatly-improved Amerpohlii. It is a compact form, much finer than Amerpohlii and does not break down in the center. The fronds are carried on wiry stems. This variety will have a wonderful sale up to a 6 -inch pot, being particularly showy for basket work. $21 / 4$-inch pots..........\$8 per $100 ; \$ 75$ per 1,000

4 -inch pots...............\$25 per 100

6 -inch pots...........\$ $\$ 6$ and $\$ 9$ per doz.

8 -inch pots...........\$12 and $\$ 15$ per doz.

\section{NEPHROLEPIS TUBEROSA PLUMOSA}

This beautiful fern is quite distinct from all of the other rarieties of the Boston Fern in so much that it has been raised from the Japan species Nephrolepis Tuberosa, which type is much hardier than the Exaltata.

The fronds are long and narrow, the pinnules beautiful plumose which are of light color, giring the fronds a beautiful effect on account of the two distinct shades as well as its graceful waviness, and will be found a great and distinct addition to collection ferns. 4 -inch pots.........\$25 per $100 ; \$ 225$ per 1,000 6 -inch pots................ \$50 per 100

6 -inch pots, heary.............\$9 per doz. 8 -inch pots, heary............\$15 per doz.

\section{NEPHROLEPIS BOSTONIENSES HARRISII}

A drarf type of the Nephrolepis Harrisii and excellent in all sizes from $t$-inch plants up.

$21 / 4$-inch pots........\$6 per $100 ; \$ 50$ per 1,000

4 -inch pots.........20 per $100 ; \$ 180$ per 1,000

6 -inch pots.........\$6 per doz.; $\$ 15$ per 100

7 -inch pots, heary......\$9 per doz.; $\$ 70$ per 100

8 -inch pots..........\$12 and $\$ 15$ per doz.

11 -inch pots..........\$2, $\$ 2.50$ and $\$ 3$ each

\section{NEPHROLEPIS BOSTONIENSES} Wm. K. Harris

The finest rariety for large plants, being a great improvement orer the old Boston.

$21 / 4$-inch pots......... \$6 per $100 ; \$ 50$ per 1.000 4 -inch pots........ \$20 per $100 ; \$ 180$ per 1.000 6 -inch pots.......... \$6 per doz.; $\$ 45$ per 100

6 -inch pots, heary.......\$9 per doz. : \$70 per 100

$s$-inch pots...........\$12 and $\$ 15$ per doz

11 -inch tubs......\$2. $\$ 2.50, \$ 3, \$ 4, \$ 5$ and $\$ 6$ each 


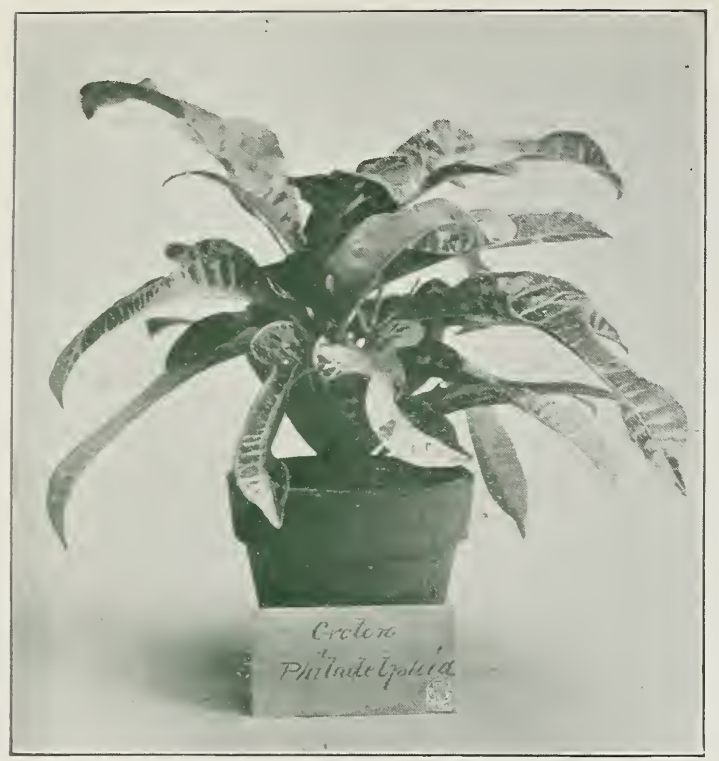

NEIT SEEDLTNG CROTON PHILADELPHIA

ASPARAGUS PLUMOSA NANUS

$21 / 4$-inch pots.........\$t per $100 ; \$ 35$ per 1,000 3 -inch pots.......... \$i per $100 ; \$ 65$ per 1,000

\section{ASPARAGUS LUTZI}

A cross between Asparagus Plumosus and Asparagus Deflexus Scandens. An excellent variety for cutting. The shoots grow five to six feet in length, perfectly upright, without tending to wind. These shoots should be supported by stakes, tying each plant to wire stakes or bamboo canes. It is a big producer, the lateral fronds being of sufficient length for cutting and these come the entire length. No bare stems at the bottom. The variety shows monderful tendency to flower and seed. It can be grown at a cooler temperature than Plumosus Nanus. It requires less head room. It makes an excellent plant for basket work.

t-inch jots, hears,

$\$ 0.60$ each; $\$ 7.50$ per doz.; $\$ 50$ per 100 5 -inch pots, heary. .\$1 each; \$10 per doz.; \$75 per 100

\section{ADIANTUM HYBRIDUM}

The best variety for either a pot plant or for cut fronds.

2 -inch pots . ........\$6 per $100 ; \$ 50$ per 1,000

3 -inch pots, heary. . . . . \$10 per $100 ; \$ 90$ per 1,000 4 -inch pots, heary......\$20 per $100 ; \$ 180$ per 1,000

6 -inch pots, heary........\$6 per doz.; $\$ 45$ per 100

8-inch pots..........\$12 per doz.; \$90 per 100 11-inch tubs............ \$24 and $\$ 30$ per doz.

\section{ASPLENIUM AVIS NIDUS}

Bird's nest fern. Plants of exceptional quality. 6 -inch pots............\$12 and $\$ 15$ per doz. 7 -inch pots.............\$24 per doz.

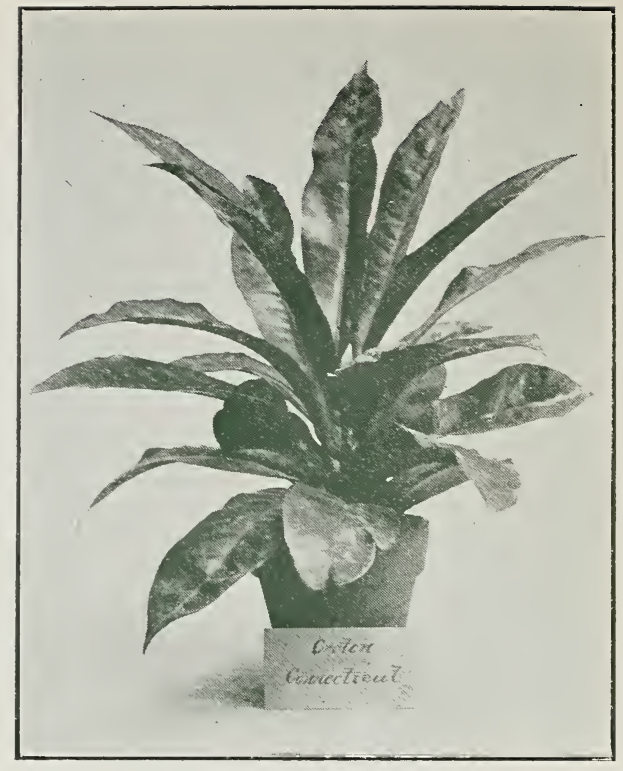

NEW SEEDLING CROTON CONNECTICUT

\section{ASPARAGUS SPRENGERII}

3 -inch pots.........\$6 per $100 ; \$ 50$ per 1,000 t-inch pots......... \$10 per $100 ; \$ 90$ per 1,000

\section{PTERIS ALEXANDRIA}

One of the rery best for fern dishes or combination baskets.

21/4-inch pots........\$7 per $100 ; \$ 60$ per 1,000 3 -inch pots........\$10 per $100 ; \$ 90$ per 1,000 4 -inch pots.............\$20 per 100

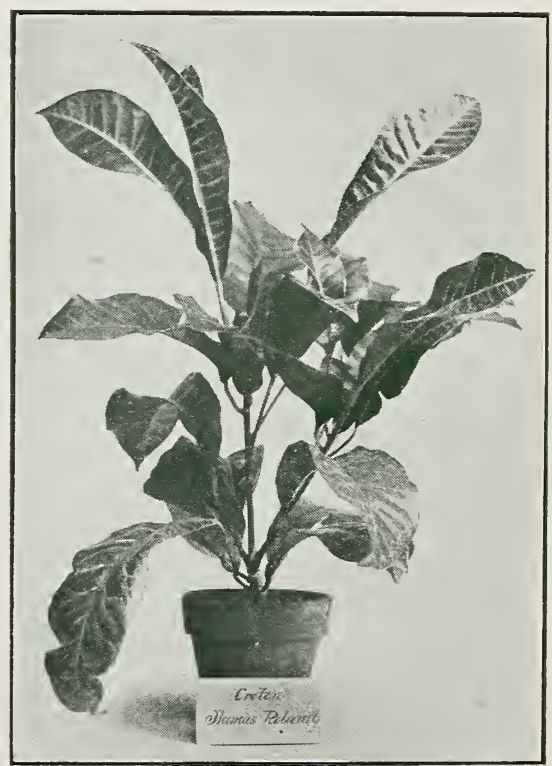

NEW SEEDLING CROTON THOMAS ROLAND 


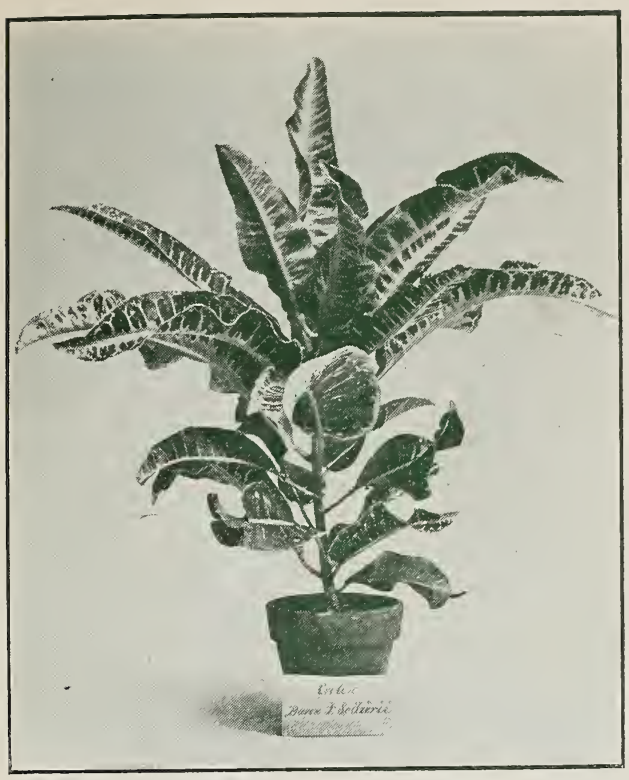

CROTON B. F. SOLLIERII

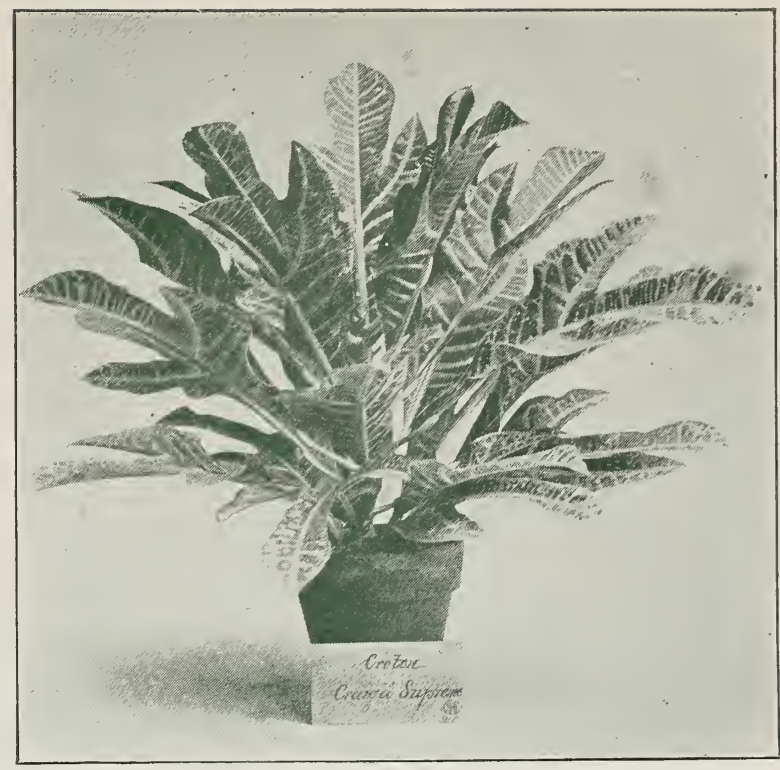

NEW SEEDLING CROTON CRAIGTI SUPREME

\section{NEW SEEDLING VARIETIES}

Our new Seedling Crotons, some of which we dis seminated in June, 1911, are varieties that should be in every grower's and private person's collection. They are far superior to many of the older varieties of. Crotons and the types range from narrow to very large leaf.

We particularly call your attention to our set of thirteen, named after the "Thirteen Original States," which have won highest honors wherever shown.

4-inch pots, strong plants,

$\$ 3$ each; $\$ 30$ per doz.; $\$ 200$ per 100

6-inch and 7-inch pots, larger plants,

$\$ 3.50, \$ 4$ and $\$ 5$ each.

\section{CROTON LEAVES AND SPRAYS}

Cut Croton Leaves and Sprays have been supplied by us in the past few years to some of the leading retail florists, who have featured them in mantle, table and funeral work. They are also especially attractive to use with Chrysanthemums.

Cut Crotons will last in a cool place from three to four weeks. We can supply them every day in the year. Very highly colored sprays at 25c., 35e. and 50c. Cut Leaves, $\$ 3$ and $\$ 5$ per 100.

When you have orders for funeral or table work "out of the ordinary," order "Craig's Cut Crotons." 


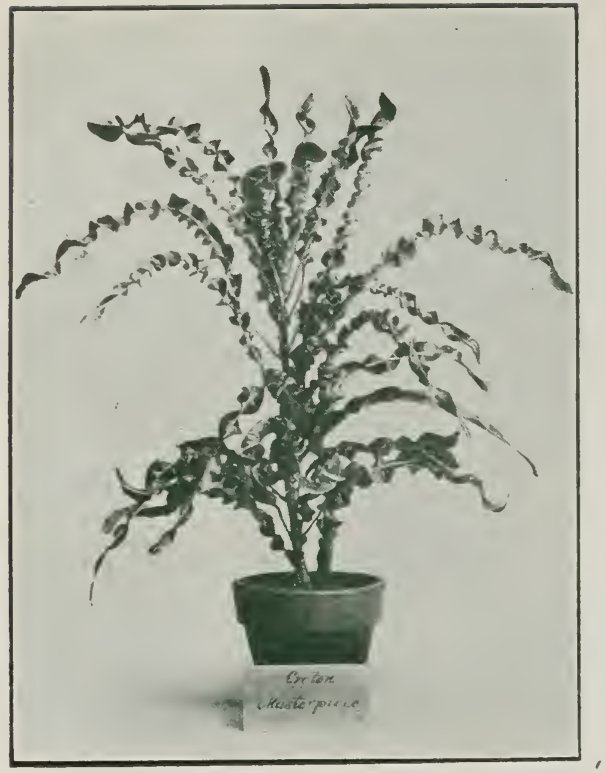

NEW SEEDLING CROTON MASTERPIECE



NEW SEEDLING ('RO'TON BALTIMORE

\section{CUT CHRYSANTHEMUMS}

We are growing over 50,000 cut blooms of Chrysanthemums in all the best commercial varieties. Ready October 1st and until December 1st. Make arrangements with us to have your "Cut Mums" supplied by us. Either daily or weekly shipments. Lowest market prices.

\section{POT CHRYSANTHEMUMS}

Large stock of Pampom varieties in 6-inch pots at $\$ 4, \$ 5$ and $\$ 6$ a doz.

\section{PELARGONIUM-EASTER GREETING}

NoveMber Delivery

21/4-inch pots, strong plants,

$\$ 10$ per $100 ; \$ 90$ per 1,000

4 -inch pots, strong plants,

$\$ 20$ per $100 ; \$ 180$ per 1,000

\section{CYRTONIUM ROCHFORDIANUM}

3-inch pots, heavy.............. \$8 per 100

4-inch pots, heavy............... \$15 per 100

6 -inch pots, heavy................\$35 per 100

\section{VERBENA-KARL MULLER}

JANUARY 1ST DELIVERY

Finest bedding verbena in existence, of the brightest scarlet color.

$21 / 2$-inch pots.......... \$5 per 100; $\$ 40$ per 1,000

3 -inch pots.........\$7 per 100;60 per 1,000

Every grower of spring plants should try this variety. 


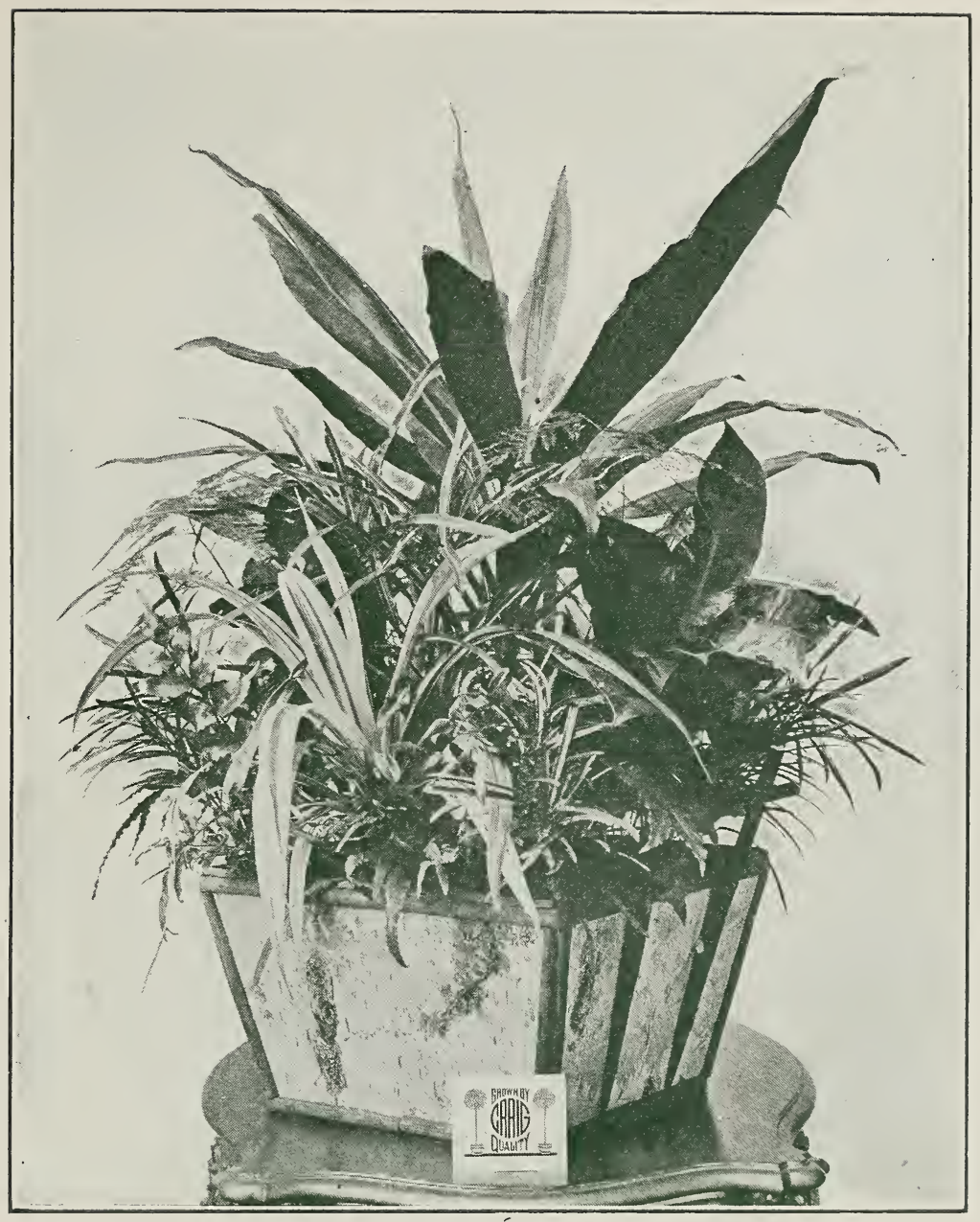

PLANT COMBINATION BASKET 


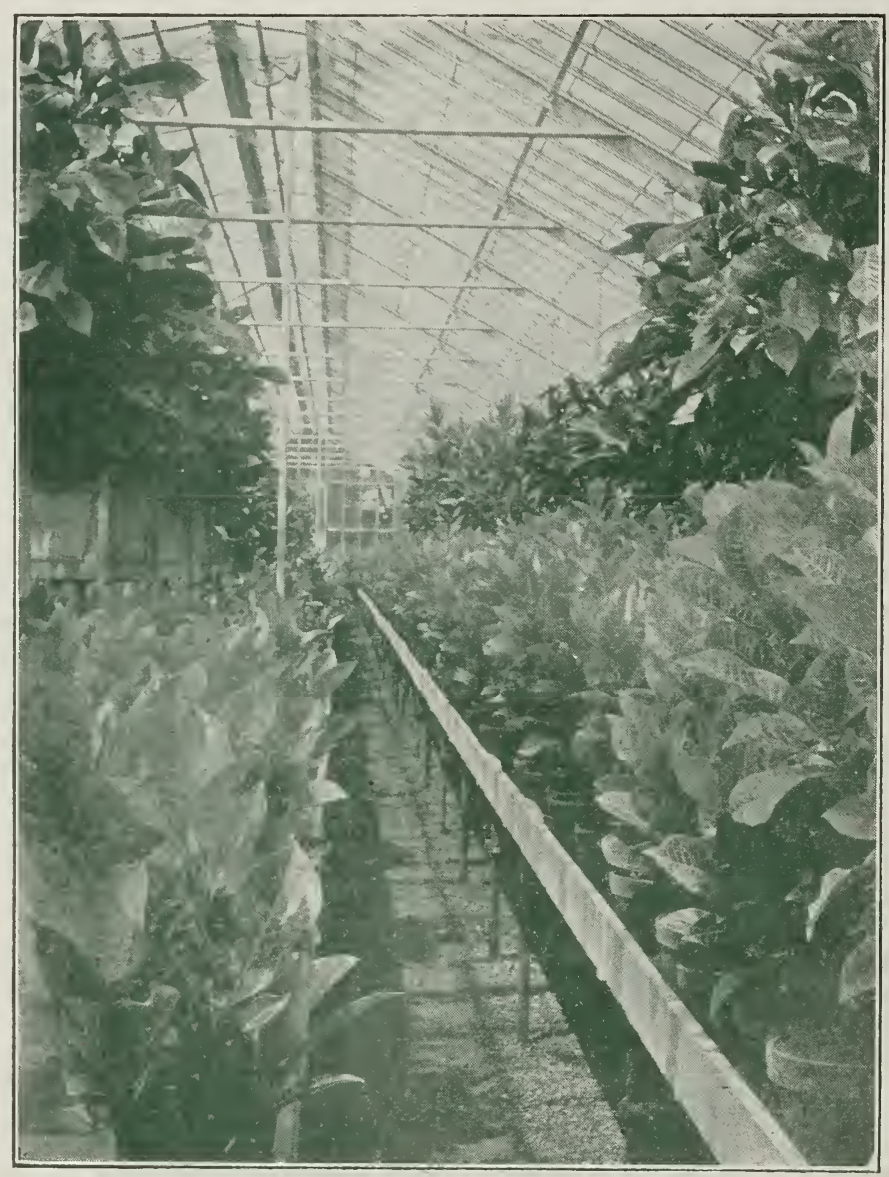

A HOUSE OF CRAIG QUALITY CROTONS 